\title{
DISTRIBUIÇÃO ESPACIAL E ABSORÇÃO DE ÁGUA PELO SISTEMA RADICULAR DA CULTURA DA MANGA (Mangifera indica L.) IRRIGADA POR MICROASPERSÃO.
}

\section{CARLOS AMILTON SILVA SANTOS}

Engenheiro Agrônomo

Orientador: Prof. Dr. RUBENS DUARTE COELHO

Dissertação apresentada à Escola Superior de Agricultura "Luiz de Queiroz", Universidade de São Paulo, para obtenção do título de Mestre em Agronomia, Área de Concentração: Irrigação e Drenagem.

\section{PIRACICABA}

Estado de São Paulo - Brasil

Novembro - 1997 


\section{Dados Internacionais de Catalogação na Publicação (CIP) DIVISÃO DE BIBLIOTECA E DOCUMENTAÇÃO - Campus "Luiz de Queiroz"/USP}

Santos, Carlos Amilton Silva

Distribuição e absorção de água pelo sistema radicular da cultura da manga (Mangifera indica L.) irrigada por microaspersāo / Carlos Amilton Silva Santos. - Piracicaba, 1997.

51 p. : il.

Dissertação (mestrado) - - Escola Superior de Agricultura Luiz de Queiroz, 1997. Bibliografia.

1. Água de irrigação (absorção) 2. Distribuição espacial 3. Irrigação por microaspersão 4. Manga 5. Raiz I. Título

CDD 631.7

634.441 


\section{DISTRIBUIÇÃO ESPACIAL E ABSORÇÃO DE ÁGUA PELO SISTEMA RADICULAR DA CULTURA DA MANGA (Mangifera indica L.) IRRIGADA POR MICROASPERSÃO.}

Aprovada em: 21.01 .1998

Comissão Julgadora:

Prof. Dr. Rubens Duarte Coelho

ESALQ/USP

Prof. Dr. Marcos Vinicius Folegatti ESALQ/USP

Prof. Dr. Ricardo Ferraz de Oliveira ESALQ/USP

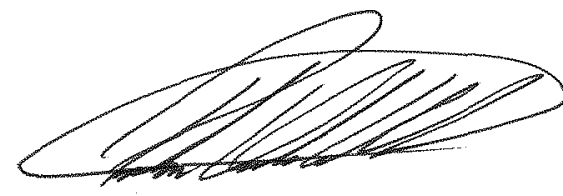

Prof. Dr. Rubens Duarte Coelho

Orientador 
Aos meus pais

Florisvaldo Teixeira Santos e Selene Silva Santos

Aos meus irmãos

\section{OFEREÇO}

A Cássia Maria Ribeiro Carrichio e Familia Ao Antônio César R. Frões e Vânia Frões (In memorian)

\section{DEDICO}




\section{AGRADECIMENTOS}

Ao amigo Prof. Dr. Rubens Duarte Coelho, pela orientação

Ao Prof. Dr. Ricardo Ferraz de Oliveira, Marcos Vinícius Folegatti pela sugestões apresentadas.

Aos professores do Departamento de Engenharia Rural pelos ensinamentos prestados.

As Professoras Izalina Ferreira Alves e Sônia Maria D. E. Piedade pela ajuda na análise estatística

A Escola Superior de Agricultura "Luiz de Queiroz" (ESALQ/USP), pela oportunidade da realização do curso.

Ao Departamento de Física do Solo do CENA (Centro de Energia Nuclear na Agricultura), pela permissão no uso das instalações.

À CAPES, pela concessão de bolsa de estudo, sem a qual não seria possível a realização do curso.

À EMBRAPA/CNPDIA e em particular a Lúcio Jorge, pela permissão do uso do programa.

A todos os colegas, em especial a Francisco Adriano de Carvalho Pereira, Antônio Melhem Saad, Lourival Fante Júnior, Fernando Cintra, Adriana Ramos, Maurício A. Coelho Filho, aos alunos de graduação Wilmara Hader e Adalberto Bassos.

Aos funcionário do Departamento, Zezinho, Gilmar, Hélio, César, Vera, pela amizade e apoio no desenvolvimento das atividades. 


\section{SUMÁRIO}

\section{Página}

LISTA DE FIGURAS ……....................................................................... vii

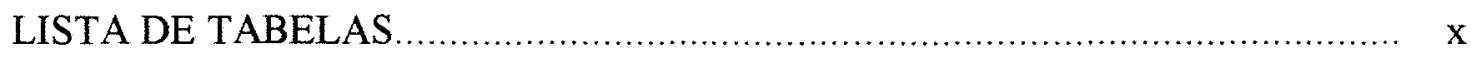

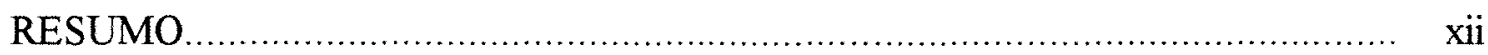

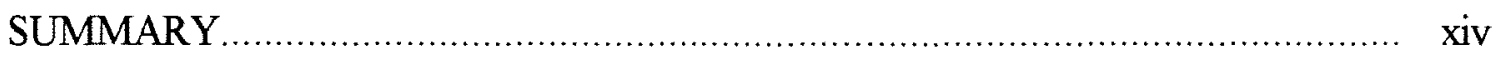

1 INTRODUÇÃO

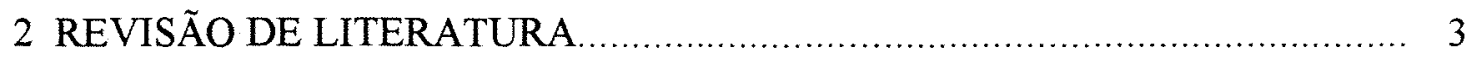

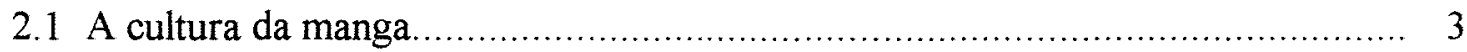

2.2 Métodos para estudo do sistema radicular .................................................. 4

2.3 Distribuição do sistema radicular................................................................... 7

2.3.1 Distribuição espacial do sistema radicular................................................ 7

2.3.2 Capacidade de absorção ................................................................... 10

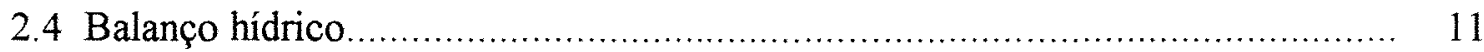

2.5 Sistemas de leituras dos tensiômetros ...................................................... 12

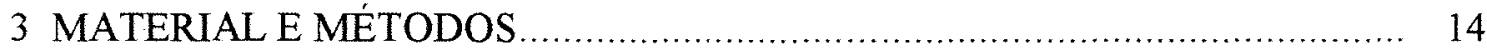

3.1 Caracterização da área experimental ..................................................... 14

3.2 Preparação da área experimental........................................................... 14

3.3 Obtenção e digitalização das imagens .................................................... 17

3.4 Delineamento estatístico para estudo da distribuição do sistema radicular........ 21

3.5 Cálculo da variação do armazenamento de água no solo com tensiômetros...... 22

4 RESULTADOS E DISCUSSÃO ............................................................ 30

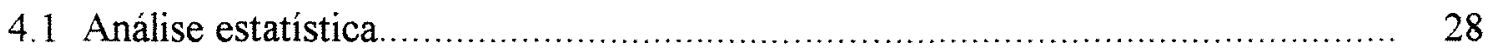


4.2 Distribuição horizontal e vertical das raizes..................................... 30

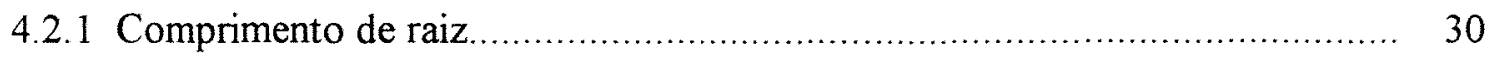

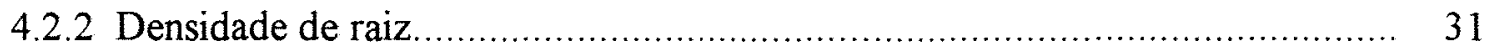

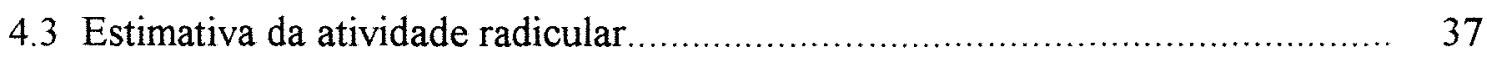

5 CONCLUSÕES........................................................................ 44

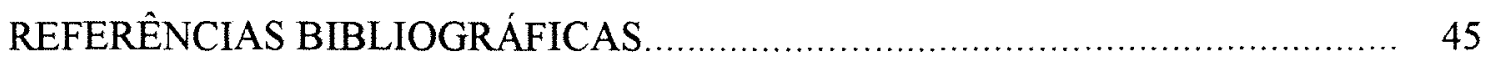




\section{LISTA DE FIGURAS}

Página

1 Área superficial de raiz e condutividade hidráulica (Lp) de plântulas de feijão (Phaseolus vulgaris). A área superficial de raiz aumenta constantemente com a idade, mas a condutividade hidráulica diminui com o envelhecimento do sistema radicular. (Fonte: Ficus \& Markhart, 1979.)

2 Esquema experimental de amostragem utilizado para quantificação da distribuição radicular através da filmagem. Disposição da tela junto à planta de manga e dimensões da quadrícula.

3 Imagem digitalizada e tratada (contraste e brilho) no CORELDRAW (a), Imagem transformada no CORELDRAW em Grayscale 8 bits (b).

4 (a) Imagem calibrada nas dimensões da quadrícula, (b) Seleção da área da quadrícula $(25 \mathrm{~cm} \times 25 \mathrm{~cm})$ 
8 Vista em planta da disposição dos tensiômetros e do emissor de irrigação em relação ao tronco da planta.

9 Dados climáticos do período da avaliação.

10 Esquema dos anéis concêntricos utilizados na quantificação do volume de água extraído pelo sistema radicular, a partir da variação de lâmina pontual no perfil...

11 (a) Exposição do sistema radicular; (b) Disposição dos tensiômetros junto à planta; (c) Ensaio do perfil de distribuição do emissor.

12 (a) Distribuição do comprimento de raiz em função da distância em relação ao tronco da planta, (b) Distribuição da densidade de raiz em função da distância em relação ao tronco da planta

13 (a) Distribuição do comprimento de raiz ( $\mathrm{cm}$ de raiz/ $\mathrm{cm}^{2}$ de solo) em função da distância do tronco da planta, (b) Distribuição do comprimento de raiz em função da profundidade, (c) Distribuição da densidade $\left(\mathrm{cm}^{2}\right.$ de raiz $/ \mathrm{cm}^{2}$ de solo) de raiz em função da distância do tronco da planta, (d) Distribuição da densidade de raiz em função da profundidade

14 (a) Isolinhas de comprimento de raiz/ $625 \mathrm{~cm}^{2}$ de solo de uma camada amostrada de $1 \mathrm{~cm}$ de espessura; (b) Isolinhas de $\mathrm{cm}$ de raiz/ volume correspondente ao anel de cada quadrícula amostrada

15 Isolinhas de densidade de raiz $\mathrm{cm} 2$ de raiz $625 \mathrm{~cm} 2$ de solo de uma camada amostrada de $1 \mathrm{~cm}$ de espessura 
16 Estimativa do consumo da solução do solo em função da lâmina $(\mathrm{mm})$

17 Estimativa da atividade radicular em função do consumo da solução do solo (litros).

18 (a) Isolinhas do potencial total (Kpa) do dia 10/10/1997; (b) Isolinhas do potencial total (Kpa) do dia 14/10/1997. 


\section{LISTA DE TABELAS}

Página

1 Composição granulométrica e densidade do solo da área experimental.............. 15

2 Quadro da análise de variância.

3 Valores de $\mathrm{n}, \mathrm{m}, \theta \mathrm{s}, \theta \mathrm{r}$ e $\alpha$ da curva de retenção de água no solo para as diversas profundidades.

4 Análise de variância dos dados transformados referentes às variáveis densidade e comprimento de raizes.

5 Regressões polinomiais significativas dos dados transformados das distâncias dentro das profundidades e das profundidades dentro das distâncias com seus respectivos coeficientes de determinação $\left(R^{2}\right)$ e valores máximos para a variável comprimento de raiz $\left(\mathrm{cm}\right.$ de raiz/ $\mathrm{cm}^{2}$ de solo).

6 Regressões polinomiais significativas dos dados transformados das distâncias dentro das profundidades e das profundidades dentro das distâncias com seus respectivos coeficientes de determinação $\left(R^{2}\right)$ e valores máximos para a variável densidade de raiz. $\left(\mathrm{cm}^{2}\right.$ de raiz/ $\mathrm{cm}^{2}$ de solo). 
7 Estimativa da atividade do sistema radicular nas diferentes camadas de $10 \mathrm{~cm}$, com umidade média das três plantas, para as distâncias de $50,100,150$ e 200 $\mathrm{cm}$ em relação ao tronco da planta 


\title{
DISTRIBUIÇÃO ESPACIAL E ABSORÇÃO DE ÁGUA DO SISTEMA RADICULAR DA CULTURA DA MANGA (Mangifera indica L.) IRRIGADA POR MICROASPERSÃO.
}

\author{
Autor: CARLOS AMILTON SILVA SANTOS \\ Orientador: Prof. RUBENS DUARTE COELHO
}

\section{RESUMO}

O presente trabalho teve por objetivo estudar a distribuição do sistema radicular da manga (Mangifera indica L.) variedade Hadem por meio de imagens digitalizadas, visando avaliar a área potencial de absorção das raízes, com base na variação do contéudo de água no solo. O trabalho foi realizado no município de Piracicaba (SP), na fazenda experimental (Fazenda Areão) da Escola Superior de Agricultura "Luiz de Queiroz", Universidade de São Paulo. Seis árvores de mangueira plantada no espaçamento $10 \times 10 \mathrm{~m}$, foram analisadas. As trincheiras foram abertas em três plantas com $1,80 \mathrm{~m}$ de profundidade $\mathrm{x} 6,0 \mathrm{~m}$ de comprimento $\times 1,5 \mathrm{~m}$ de largura, distante do tronco da planta $0,5 \mathrm{~m}$, no sentido paralelo a linha de plantio. O perfil do solo foi cuidadosamente escavado em uma profundidade de $1 \mathrm{~cm}$, procurando preservar o sistema radicular na camada existente. Uma vez exposto todo o sistema radicular no perfil, efetuou-se a filmagem em vídeo K-7 do mesmo, visando posterior processamento das imagens pelo software SIARCS/EMBRAPA. A avaliação da área potencial de 
absorção foi realizada em três plantas, por meio do balanço de água no solo, com auxilio de tensiômetros digitais de punção, os quais foram instalados em número de 40 por planta, distribuídos em quatro baterias distanciadas $50,100,150$ e $200 \mathrm{~cm}$ do tronco da planta até $100 \mathrm{~cm}$ de profundidade a intervalos de $10 \mathrm{~cm}$. A partir dos resultados obtidos, pode-se concluir que: para fins de monitoramento de irrigação localizada, a faixa ideal de instalação dos instrumentos e sensores de umidade do solo esta entre $100-150 \mathrm{~cm}$ em relação ao tronco da planta e entre $10-40 \mathrm{~cm}$ de profundidade; a zona de maior atividade de absorção de água coincide com a zona de maior concentração $\left(\mathrm{cm}^{2}\right.$ de raiz/ $\mathrm{cm}^{2}$ de solo e $\mathrm{cm}$ de raiz/ $\mathrm{cm}^{2}$ de solo) do sistema radicular. 


\title{
SPATIAL DISTRIBUTION AND WATER UPTAKE \\ BY MANGO CROP (Mangifera indica $L$.) IRRIGATED BY MICROSPRINKLER.
}

\author{
Author: CARLOS AMILTON SILVA SANTOS \\ Adviser: Prof. RUBENS DUARTE COELHO
}

\section{SUMMARY}

The present work had for objective to study the distribution of the root system of the mango crop (Mangifera indica L.) variety Hadem by means of digital images inorder to evaluate the potential area of roots uptake based on the variation of soil moisture content. The work was accomplished in the Piracicaba city (SP), in the irrigation experimental station (Fazenda Areão) of the Escola Superior de Agricultura "Luiz de Queiroz ", University of São Paulo. Six trees planted in the spacing $10 \times 10 \mathrm{~m}$ were analyzed. The trenches were opened with $1,80 \mathrm{~m}$ of depth $\times 6,0 \mathrm{~m}$ of length $\times 1,5$ $\mathrm{m}$ of width, distant to the trunk of the plant $0,5 \mathrm{~m}$, in the parallel sense the plantation line (three plants were sampled). The profile of the soil was dug carefully in a depth of $1 \mathrm{~cm}$, trying to preserve the root system in the existent layer. Once exposed the whole root system in the profile, it was record in video K-7 camera for posterior processing of the images throught the SIARCS/EMBRAPA solftware. The evaluation of the potential area of uptake was accomplished by means of the water in the soil in the other three plants, based on digital punction tensiometers readings, which were installed in number of 40 
for plant, distributed in four distanced batteries $50,100,150$ and $200 \mathrm{~cm}$ around the plant trunk up to $100 \mathrm{~cm}$ of depth to intervals of $10 \mathrm{~cm}$. From the obtained results, it can be ended that: for controlling irrigation depth, the ideal strip of installation of the tensiometers between $100-150 \mathrm{~cm}$ in relation to the trunk of the plant and enter between $10-40 \mathrm{~cm}$ of depth; the zone of larger activity of uptake of water coincides with the zone of higher root concentration $\left(\mathrm{cm}^{2}\right.$ of root $/ \mathrm{cm}^{2}$ of soil and $\mathrm{cm}$ of root $/ \mathrm{cm}^{2}$ of soil). 


\section{INTRODUÇÃo}

A manga (Mangifera indica L.) figura entre as mais importantes frutas tropicais do mundo, após a banana e o abacaxi. O seu aroma, sabor fino, alto valor nutritivo e sua boa aceitação no mercado mundial principalmente Europa, tem contribuído à expansão das áreas irrigadas com essa cultura no Brasil .

Segundos dados do Agrianual (1998), há cerca de 55 mil hectares plantados com mangueira no Brasil, sendo uma das principais fruteiras em expansão nos perímetros irrigados.

Por ser uma planta de áreas subtropicais e por manter-se sempre verde com alto grau de turgor na folha, a mangueira é considerada uma das fruteiras mais tolerantes à seca (Farré \& Hermoso, 1993). Essa resistência é relativa, pois depende da severidade do estresse hídrico. Como se trata de uma espécie do trópico úmido e por ser plantada em regiões em que a distribuição pluviométrica não é uniforme, em períodos de estiagem prolongada é necessário um complemento de água sob a forma de irrigação, para que se obtenha um crescimento normal e produção adequada.

A seleção do sistema de irrigação mais apropriado apresenta-se ligada às condições topográficas, recursos hídricos, qualidade da água, economicidade do sistema, eficiência da irrigação e disponibilidade de mão-de-obra (Scaloppi, 1986). Uma vez escolhido e implantado o sistema, a questão seguinte é o conhecimento das interrelações do sistema água - solo - planta - atmosfera, para o manejo adequado da irrigação.

Dentre estas relações, o conhecimento da profundidade efetiva do sistema radicular é um importante parâmetro utilizado nos cálculos e no monitoramento da irrigação. É importante também para determinar a localização adequada do fertilizante no momento da aplicação, tratos culturais que poderão ser melhor explorados. Além de ser 
empregado em modelos de absorção de água e nutrientes, os quais em sua maioria requerem determinações da densidade e comprimento de raizes.

Estudos simultâneos de raiz e copa apresentados em literaturas, restringem-se a medidas de peso seco de raízes ao final do experimento. Raramente foram mensurados comprimento ou área superficial de raiz, que permitisse avaliar a área potencial para absorção da solução do solo.

O presente trabalho tem por objetivo estudar a distribuição do sistema radicular da manga (Mangifera indica L.) variedade Hadem, visando avaliar a área potencial de absorção das raizes por meio da variação da umidade do solo, estimada com base na variação do potencial mátrico (tensiômetro digital de punção). 


\section{REVISÃO DE LITERATURA}

\subsection{A cultura da manga.}

Segundos dados da FAO de 1996, a Índia é o maior produtor mundial, com $52,82 \%$ da produção total de mais de 18 milhões de toneladas, vindo depois México $(7,2 \%)$, China (6\%), Paquistão $(4,43 \%)$, Tailândia $(3,43 \%)$ e o Brasil com $2,11 \%$ do mercado mundial.

A manga destaca-se como uma fruta de alto valor comercial em muitas regiões do mundo, principalmente nas zonas tropicais e subtropicais. O Brasil é o principal produtor na América do Sul, contribuindo com $55 \%$ da produção total do Cone Sul (FAO, 1995). Dentre as regiões do país o Nordeste e Sudeste são responsáveis por $90 \%$ da produção nacional.

A produção e a área plantada nos últimos anos sofreu um aumento significativo, despontando como uma opção para as novas fronteiras agrícolas que estão surgindo, principalmente para áreas irrigadas. Os principais motivos atribuídos a este crescimento são: possibilidade de maior produtividade em relação aos cultivos de sequeiros e expansão dos mercados interno e externo.

As importações de frutas brasileiras realizadas pelos paises europeus cresceram $70 \%$ nas últimas décadas. Isto ocorreu, devido às boas condições edafoclimáticas que o país oferece e a possibilidade de produzir frutos durante a maior parte do ano, mediante o uso de técnicas de indução floral e manejo da irrigação.

As áreas que mais se adaptam ao desenvolvimento da cultura são as que possuem estação seca e chuvosa bem definidas, com precipitação pluviométrica em torno de 500 a $2500 \mathrm{~mm}$ anuais. A faixa ideal de temperatura situa-se entre $20^{\circ} \mathrm{C}$ a $26^{\circ} \mathrm{C}$, 
visto que a temperatura age sobre o florescimento e influencia a época de colheita, antecipando ou retardando-a.

A umidade relativa do ar maior que $60 \%$, favorece o aparecimento de doenças como por exemplo a antracnose (Simão, 1971). Ventos fortes e constantes provocam queda das flores e frutos, podendo a causar mais de $20 \%$ na queda de produção, quando os frutos se encontram na fase terminal do seu desenvolvimento. Quanto aos solos, a planta se adapta a quase todo tipo, desde que sejam profundos, bem drenados, permeáveis e ligeiramente ácidos.

\subsection{Métodos para estudo do sistema radicular.}

Existem diferentes métodos para analisar a distribuição do sistema radícular no perfil do solo. Böhm (1979), relacionou alguns: a) escavações, b) monólitos, c) perfurações com trado, d) trincheiras, e) parede de vidro, f) avaliação indireta, g) planta em vasos h) elemento marcado, entre outros. Com o avanço da informática surgiram novas metodologias para analise do sistema radicular, dentre as quais destaca-se o método da utilização de câmera de vídeo e análise de imagens.

O método da escavação consiste em expor completamente o sistema radícular, por meio da remoção de todo o solo circundante em cada planta (Böhm, 1979), tornando possivel medir o comprimento, observar a localização das raizes, podendo ser desenhada, fotografada ou montada conforme objetivo do estudo. Segundo Kopke (1981), trata-se de um método que demanda muito tempo e tem alto custo, com perda de raizes muito pequenas.

O método monolítico, consiste na retirada de blocos de solo com raízes, dividindo-os em dimensões definidas e posterior lavagem para separação das mesmas. Este método proporciona medidas quantitativas (massa e comprimento) das raízes que são representadas por gráficos (Kopke, 1981; Zanette \& Comem, 1992). Trata-se de um método fácil e não muito trabalhoso. Pela precisão dos dados obtidos, este método tem sido usado para comparar a eficiência de outros mais simplificados (Böhm et al. 1979). 
Uma adaptação feita ao método monolítico é a placa com pregos, que pressionada contra a trincheira onde se encontram as raizes, retira-se um bloco de solo, onde estas mantêm sua posição original após a lavagem devido à presença dos pregos, fornecendo dados de distribuição no perfil e profundidade máxima (EMBRAPA, 1996; Shuurrman \& Goedewaagen, 1971).

As avaliações feitas por meio do método monolítico e da placa com pregos, danificam parte da parcela experimental, devido à grande remoção de solo, não sendo recomendada para parcelas pequenas e que estejam avaliando rendimento. Não pode ser empregado em solos pedregosos e pode ser problemático em solos muito arenosos, especialmente quando secos (Böhm, 1979).

$\mathrm{O}$ método do trado de borda serrilhada tem sido empregado por muitos pesquisadores no estudo do sistema radicular de árvores frutíferas e de outras espécies. Consiste da retirada de amostras a diferentes profundidades e distâncias do tronco da planta, após a qual as raízes são separadas do solo por meio da lavagem e limpeza das amostras, fornecendo peso de raízes, o comprimento, o raio e a superfície radicular. Permite fazer comparações com relativa rapidez da posição das raízes sem distorções causadas pelo método de escavação total e trata-se de um método simples e barato (Atkinson, 1980).

Uma variação do método acima, é a quebra do torrão retirado pelo trado o que elimina a necessidade de lavagem e limpeza das amostras (Kopke, 1981). A amostra do solo é segurada firmemente com as mãos e uma força deve ser aplicada de tal forma que o torrão de solo se quebre numa posição pré-determinada; as raízes são quantificadas nos planos de clivagem.

Esses métodos (trado e torrão), causam poucos danos no campo experimental, fornecem informações quantitativas sobre a distribuição das raizes, especialmente de espécies com raízes fibrosas e de distribuição relativamente uniforme em cada profundidade do solo (Kopke, 1981).

Uma outra forma de estudar o sistema radicular é através do rizotron (Huck \& Taylor, 1982), que consiste de uma parede de vidro ou de plástico colocada junto ao perfil do solo, através da qual é possível o acompanhamento do 
desenvolvimento de raizes e permite determinações sucessivas em uma mesma planta. No entanto, trata-se de um método trabalhoso e caro, devido à construção de instalações especificas para o acompanhamento do desenvolvimento radicular.

O minirizotron, outro método empregado no estudo de raiz, consiste de um pequeno tubo de vidro introduzido no solo, para observar as raízes com o auxilio de espelhos e técnicas de iluminação. Atualmente, o espelho foi substituído por uma fibra óptica conectada a uma micro-câmera, que permite a observação do crescimento do sistema radicular, profundidade e densidade (Taylor, et al., 1988). Por ser um método sofisticado, exige o envolvimento de pessoas qualificadas.

$\mathrm{O}$ método da trincheira ou parede de perfil, consiste da abertura de uma trincheira para a exposição das raízes de uma ou mais plantas remove-se uma fina camada da parede do perfil, de modo a expor as raízes, por meio de jatos d'água ou ferramentas manuais. Utiliza-se uma tela que é colocada de encontro à parede do perfil onde se estima o comprimento das raízes por quadrícula (Zanette \& Comem, 1992). Apesar das vantagens que the são atribuídas, tem como crítica comum o caráter de avaliação essencialmente qualitativa, com elevado grau de subjetividade (Cintra \& Neves, 1996).

Com o auxílio de técnicas de processamento de imagens digitais aliadas ao método da trincheira, elimina-se grande parte da subjetividade e o caráter qualitativo da análise, além de imprimir velocidade e precisão da análise dos dados, fato constatado por Crestana, et al. (1994). Método empregado por Fante Júnior (1997) no estudo do sistema radicular de aveia.

$\mathrm{O}$ método do elemento marcado consiste em colocar isótopos no solo, e depois constatar sua presença na parte aérea, o que indica que as raízes desenvolveramse até a posição em que o elemento foi colocado. Normalmente o mais usado é o ${ }^{32} \mathrm{P}$ devido à sua pouca mobilidade a diferentes distâncias e profundidades da planta,

Segundo Böhm (1979), dentre os métodos de avaliação indireta encontrase o decréscimo da água no solo com o tempo, que se baseia na hipótese de que a taxa de variação de umidade encontra-se correlacionada com a quantidade de raizes. Este método apresenta a vantagem de não ser destrutivo, porém algumas considerações 
devem ser feitas. Durante o período das medições não deve existir fluxo significativo de água de uma camada para outra; assume-se que a única perda seja por transpiração. Nesse caso, em períodos que ocorram precipitações freqüentes o trabalho pode ser prejudicado, visto que a permanência do solo em potencial mátrico elevado, sem ocorrer variações na umidade do solo, não representam bem a extração de água pelas raizes.

\subsection{Sistema radicular.}

\subsubsection{Distribuição espacial do sistema radicular}

O estudo do sistema radícular das plantas cultivadas vem tomando grande impulso nos últimos anos, devido às pressões econômicas para reduzir custos de produção, visto que, ao se conhecer melhor o comportamento do sistema radicular da cultura, saber-se-á como manejar melhor às culturas no que se refere a práticas de adubação, lâminas de irrigação e outros tratos culturais.

Acredita-se que a mangueira apresenta sistema radicular bastante extenso,

e profundo; Stephenes (1949), observou que ${ }^{-}$as raízes de mangueira atingiam a profundidade de até 5,5 metros.

Choudhury \& Soares (1992) empregando o método do monolítico, estudaram o comportamento do sistema radicular de mangueira irrigada em solo arenoso com problema de adensamento, verificando que $68 \%$ das raízes de absorção e $86 \%$ das de sustentação estão localizadas a distâncias de 90 a $260 \mathrm{~cm}$ em relação ao caule, respectivamente, numa faixa de profundidade do solo de 0 a $100 \mathrm{~cm}$.

Mangueiras "Oliveira Neto" e "Imperial" enxertadas sobre os portaenxertos "Espada" e "Coco" com 23 anos de idade, plantadas em solo do grupo latossol série "Luiz de Queiroz", foram avaliadas quanto à distribuição do sistema radicular pelo método do trado (Rojas, 1989). Segundo o autor, nos primeiros $30 \mathrm{~cm}$ de profundidade têm-se, aproximadamente $46,77 \%$ das raízes e $70,57 \%$ até os $60 \mathrm{~cm}$ de profundidade. $\mathrm{Na}$ distribuição horizontal, a maior concentração das radicelas encontrava-se a 100 e $200 \mathrm{~cm}$ de distância do tronco, com 35,27\% e 25,89\% respectivamente. A cultivar "Espada" apresentou maior quantidade de radicelas nos primeiros $60 \mathrm{~cm}$ de profundidade. 
Medina-Urrutia (1984), no México, estudando a distribuição radicular para diferentes cultivares (Kent, Haden e Diplomata), verificou que, para a variedade Haden, a maior concentração radicular encontrava-se entre $20-40 \mathrm{~cm}$ de profundidade, enquanto que, para as variedades Kent e Diplomata encontrava-se entre $0-20 \mathrm{~cm}$.

Avilán et al. (1979), utilizando o método da "trincheira", trabalhando com mangueiras da variedade Haden, enxertadas sobre porta - enxertos de manga "Crioulo", verificaram que a maior concentração radicular localizava-se nos primeiros $40 \mathrm{~cm}$ de profundidade, sendo relativamente escassa a presença de raizes a profundidades maiores. Lateralmente a maior concentração de raizes finas (menor de $0,5 \mathrm{~cm}$ e entre 0,5 e $2 \mathrm{~cm}$ de diâmetro) estava situados a $200 \mathrm{~cm}$ de distância do tronco da planta.

Segundo Narayana Rao \& Rameshwar ${ }^{1}$, citados por Thakur et al.(1981), em trabalho desenvolvido na Índia, em plantas da cultivar "Banganapally" com 18 anos de idade, constataram que a maioria das radicelas estavam presentes até os $60 \mathrm{~cm}$ de profundidade a $200 \mathrm{~cm}$ de distância do tronco.

Um estudo sobre distribuição do sistema radícular da manga, variedade Hadem com 7 anos de idade, foi realizado na Venezuela por Avilán (1974), empregando o método da trincheira, com perfis situados lateralmente a $0,150,350$ e 500 centímetros, respectivamente do tronco da planta, a $190 \mathrm{~cm}$ de profundidade e $200 \mathrm{~cm}$ de comprimento, verificou que: a maior concentração radicular encontrava-se a $15 \mathrm{~cm}$ lateralmente do tronco e a $110-170 \mathrm{~cm}$ de profundidade.

Kotur et al. (1997), trabalhando com técnica radioativa durante período chuvoso (setembro - novembro, final das chuvas de verão) inverno (dezembro fevereiro) e verão (março - maio), constatou que $80 \%, 80 \%$ e $53 \%$, respectivamente, da atividade radicular estava a distância de $100 \mathrm{~cm}$ em relação tronco da planta e que $46 \%$, $30 \%$ e $43 \%$ da atividade restringia-se a camada de 0-20, respectivamente.

$\mathrm{Na}$ Índia, Bojappa \& Singh (1974) utilizando a técnica de elemento marcado, estudaram onde se localizava a zona radicular mais ativa do sistemas radicular de mangueiras, em diferentes épocas do ano (outubro de 1970 e fevereiro de 1972) às

\footnotetext{
${ }^{1}$ NARAYANA RAO, M.; A. RAMESHWAR. Res. report on mango of A.I.C.F.I.P. Mtg. Held. at Gao, Panaji, India 2- 5 th May, 1979, p. 181.
} 
profundidades de 30,60 e $90 \mathrm{~cm}$ em outubro e 15,30 e $60 \mathrm{~cm}$ em fevereiro, às distâncias de $120,240,300$ e $360 \mathrm{~cm}$ do tronco da planta. Os autores observaram que em outubro, a zona de maior absorção estava às profundidades de $30 \mathrm{e} 60 \mathrm{~cm}$ nas distâncias de $120 \mathrm{e}$ $300 \mathrm{~cm}$ do tronco, respectivamente, e em fevereiro a maior atividade foi observada a 30 $\mathrm{cm}$ de profundidade, para às distâncias de $120 \mathrm{e} 300 \mathrm{~cm}$ do tronco da planta.

Bojappa \& Singh (1973), estudando a distribuição de radicelas de plantas de manga do cultivar. Dashehari, de 18 e 25 anos de idade, observaram que a maior concentração das radicelas, encontravam-se a $60 \mathrm{~cm}$ de profundidade e 60 e $120 \mathrm{~cm}$ de distância do tronco. Observaram ainda que a concentração decresceu com o aumento da distância do tronco e da profundidade do solo, existindo cerca de $35,7 \%$ e $45,4 \%$ para ambos os casos, respectivamente, a profundidade de $0-15 \mathrm{~cm}$.

Segundo Khan (1960), em estudo do sistema radicular desenvolvido no Paquistão em mangueiras com 18 anos de idade, observou que a maior concentração do sistema radicular $(94,5 \%)$ concentrava-se a $30 \mathrm{~cm}$ de profundidade à distância de 150 $\mathrm{cm}$ do tronco. Por outro lado, 93,3\% do total das raízes estavam concentradas dentro do raio de $180 \mathrm{~cm}$ da árvore e que a zona de maior atividade encontrava-se $120 \mathrm{~cm}$ de profundidade.

Na Flórida, Ford (1953) utilizou o método do trado e determinou a profundidade do sistema radicular de plantas de laranja Valência com 29 anos de idade e verificou que as plantas apresentavam cerca de $60 \%$ de suas raizes até $75 \mathrm{~cm}$ de profundidade e cerca de $90 \%$ a $150 \mathrm{~cm}$ de profundidade, em solo ácido, arenoso e profundo.

Castle (1980), também na Flórida, estudou a distribuição do sistema radicular de laranja "Pineapple" enxertada sobre limão "Rugoso" em três espaçamentos de plantio, em solo arenoso. Verificou que as raízes de diâmetro menor ou igual a $2 \mathrm{~mm}$, coletadas com trado, apresentavam maior concentração nos plantios adensados, compensando o menor volume de solo explorado.

No Brasil, o pioneiro em estudo de sistema radicular em citros foi Montenegro (1960), ele avaliou o sistema radicular de oito porta-enxertos sob copa de três variedades de laranja, utilizando o método do trado. Segundo o autor cerca de $90 \%$ 
das raizes com diâmetro menor ou igual a $1,5 \mathrm{~mm}$, encontrava-se nos primeiros $60 \mathrm{~cm}$ do solo. O autor também afirmou que, a maior quantidade de raízes de uma planta nem sempre corresponde a maior copa

Pace \& Araújo (1986), utilizando o método da trincheira estudaram a distribuição das raízes em três porta-enxertos (limão "Cravo", limão "Volkameriano" e Poncirus trifoliata L.) todos enxertados sob copa de laranja "Natal" em solo podzolizados. Para todos os casos, os autores verificaram que a maior concentração das radicelas estava a $20 \mathrm{~cm}$ de profundidade e apresentavam sensível redução na zona de transição de horizontes A e B. Dentre os porta-enxertos o que apresentou maior ocupação foi o "Volkameriano" e o menor Poncirus trifoliata L.

\subsubsection{Capacidade de absorção}

Segundo Kramer (1983), a capacidade das raízes em absolver água e minerais não é diretamente proporcional ao comprimento e a área de raízes. Todavia, essa é produto da área superficial pela condutividade hidráulica ou permeabilidade das raizes ou seja:

$$
\mathrm{Lr}=\mathrm{Lp} \times \mathrm{Ar}
$$

Onde: $\operatorname{Lr}\left(\mathrm{cm}^{3} \cdot \mathrm{s}^{-1} \cdot \mathrm{bar}^{-1}\right)$ é a capacidade do sistema radicular em absorver a solução do solo; $\mathrm{Lp}\left(\mathrm{cm}^{3} \cdot \mathrm{cm}^{-2} \cdot \mathrm{s}^{-1} \cdot \mathrm{bar}{ }^{-1}\right)$ condutividade ou permeabilidade das raízes; $\mathrm{Ar}\left(\mathrm{cm}^{2}\right)$ área da raiz.

Ficus \& Markhart (1979), estudaram a quantidade e a capacidade de absorção (Lr) de raízes de feijão. Segundo os autores a condutividade hidráulica (Lp) do sistema radicular muda de maneira complexa com a idade e com incremento da área superficial. Ocorrendo um rápido incremento na permeabilidade (Lp) em raízes jovens, seguida por um decréscimo ao iniciar as raizes velhas. Vindo logo após um pequeno incremento, provavelmente devido ao incremento de raizes novas, Figura 1. 


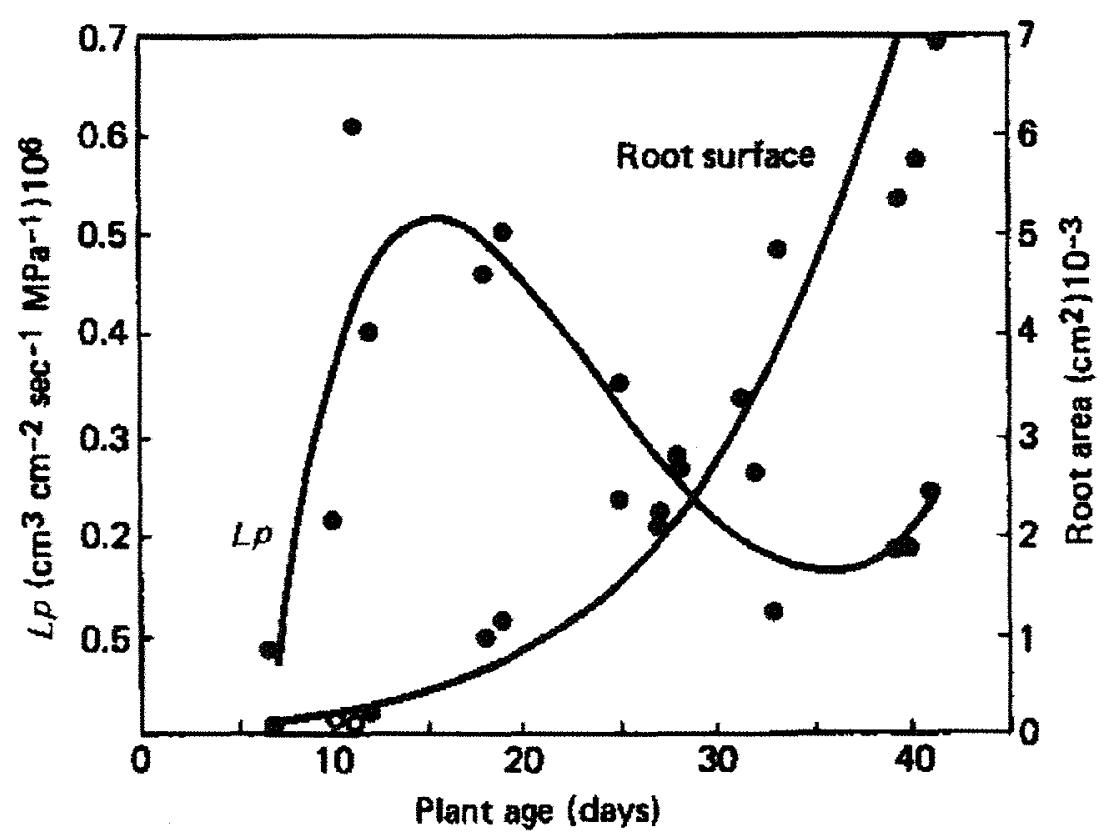

Figura 1: Área superficial de raiz e condutividade hidráulica (Lp) de plântulas de feijão (Phaseolus vulgaris). A área superficial de raiz aumenta constantemente com a idade, mas a condutividade hidráulica diminui com o envelhecimento do sistema radicular. (Fonte: Ficus \& Markhart, 1979.)

\subsection{Balanço hídrico}

A água, para as culturas constitui um fator primordial à realização dos processos fisiológicos da planta que, por sua vez, define o sucesso ou fracasso da produção.

Com o objetivo de melhor manejar esse fator, diversos autores entre eles; Saad (1991; 1996); Reichardt et al. (1979); Cruciani (1972) dentre outros, fizeram uso da metodologia empregada no balanço hídrico para determinar o consumo de água para algumas culturas.

Esta metodologia utiliza-se de um volume de solo conhecido, no qual se mede as variações entrada e saida de água, num determinado intervalos de tempo $(\Delta T)$ Libardi (1995). Considera-se como entrada de água no volume de solo, a soma das quantidades de água provenientes da chuva, da irrigação e da ascensão capilar, e 
considera-se como saída de água, as quantidades de água provenientes da drenagem profunda, evapotranspiração e escoamento superficial. O volume de solo depende da cultura em estudo, o qual deve englobar seu sistema radicular.

Segundo Reichardt et al. (1979), na elaboração do balanço hídrico a maior dificuldade encontra-se em se estimar os fluxos ascensão capilar e drenagem profunda, dados esses obtidos a partir da equação de Darcy. Esta dificuldade ocorre devido a erros cometidos na estimativa do gradiente de potencial $\partial \Psi / \partial z$ da equação, e principalmente na escolha do valor da condutividade hidráulica que, sendo uma função exponencial, um erro pequeno na estimativa da umidade, altera, em muito, o valor da condutividade.

Esses autores relatam tratar-se de uma metodologia bastante complexa; sendo imprescindivel para o conhecimento profundo das relações água - solo - planta em uma cultura.

\subsection{Sistema de leituras dos tensiômetros.}

O manejo da irrigação consiste no monitoramento da umidade do solo próximo à zona radícular. Diversos instrumentos têm sido desenvolvidos com o objetivo de detectar, de forma rápida e precisa o momento de irrigar. O tensiômetro, entretanto, é o mais comum, por fornecer uma medida direta do potencial mátrico da água no solo, que se relaciona com a umidade do solo por meio da curva de retenção de água no solo.

$\mathrm{O}$ tensiômetro geralmente é constituído por um tubo plástico, preenchido com água, tendo na sua extremidade inferior uma cápsula de cerâmica e na parte superior uma tampa. Próxima a essa, normalmente encontrá-se conectado um manômetro de mercúrio ou do tipo "Bourdonn" (Klar, 1984). Ultimamente, têm surgido outros tipos de tensiômetros que utilizam outros sẹnşores de vácuo. Por exemplo, tem-se o transdutor eletrônico portátil de punção conectado ao tensiômetro através de uma agulha de seringa (Marthaler et al., 1983); outro tipo é o de câmara de ar desenvolvido por Paes de Camargo et al.(1982).

Segundo Hillel (1970) a faixa de funcionamento do tensiômetro limita-se entre 0 a 0,8 atm. $O$ autor sugere seu uso no controle de irrigação em culturas sensíveis a 
baixo potencial mátrico $(0-0,7 \mathrm{~atm})$. Mesmo com essa limitação, Reichardt (1990) afirma que é um ótimo instrumento de campo para indicar o momento de irrigar, tendo em vista que a maior percentagem de água disponível para as plantas cultivadas, encontra-se nessa faixa de tensão.

Thiel et al. (1963) foram os primeiros a desenvolver um transdutor elétrico para medir pressões hidrostáticas em material poroso. O principio de funcionamento baseia-se na deflexão de um diafragma circular de aço inoxidável em função das pressões aplicadas. Segundo os autores, o transdutor deve ser calibrado antes da instalação, e a curva de calibração é feita pela relação entre saída elétrica (Volts) e pressão aplicada.

Um tensiômetro de punção digital foi desenvolvido por Marthaler et al. (1983), constituído de um transdutor de pressão portátil ligado ao tensiômetro, por meio de uma agulha de seringa, tendo um registrador digital. Para promover a leitura de um tensiômetro era introduzida a agulha através de uma tampa de borracha presente na extremidade superior do aparelho. A pressão do ar, presente numa pequena câmara deixada abaixo da tampa de borracha, equilibra-se com a pressão na água do tensiômetro, sendo a leitura indicada num registrador digital. Segundo os autores, o uso deste tipo de instrumento permite uma manutenção rápida em relação ao tensiômetro de coluna de mercúrio, além de diminuir a influência da temperatura e a chance de danos mecânicos.

Cresswell (1993), analisando o aparelho desenvolvido por Marthaler et al., observou que a agulha introduzida na tampa de borracha provocou mudanças na pressão no seu interior, de tal forma que um tempo de 2 horas foi necessário para que ocorresse o reequilibrio com a pressão original antes de uma nova introdução da agulha. Como em resultados anteriormente observados pelos autores, esse tempo foi maior para potenciais menores diminuindo com o aumento da câmara de ar deixada no interior do tensiômetro. Para efeito prático o autor recomenda que a leitura seja feita no momento da conexão do transdutor, e que posteriormente se faça a correção por meio de curvas padrões de reequilibrio previamente determinadas. 


\section{MATERIAL E MÉTODO}

\subsection{Caracterização da área experimental}

O trabalho foi realizado no municipio de Piracicaba, localizada geograficamente nas coordenadas $22^{\circ} 42^{\prime} 30^{\prime \prime}$ Sul e $47^{\circ} 30^{\prime} 00^{\prime \prime}$ Oeste, a 576 metros acima do nível do mar, no campo experimental de Irrigação (Fazenda Areão), vinculado ao Departamento de Engenharia Rural da Escola Superior de Agricultura "Luiz de Queiroz", Universidade de São Paulo.

O clima, segundo a classificação de Köppen, é do tipo Cwa ( Tropical úmido com três meses mais secos: junho, julho e agosto), com chuvas de verão. Apresenta médias anuais: (a) precipitação $1253 \mathrm{~mm}$, (b) temperatura $21,1{ }^{\circ} \mathrm{C}$, (c) umidade relativa $74 \%$, (d) velocidade do vento $2,2 \mathrm{~m} / \mathrm{s}$ com direção E/SE predominantemente (média de 71 anos; 1917 a 1987) (Ometto, 1991).

O local do experimento possui declividade média de $4 \%$ e o relevo é suavemente ondulado. O solo é classificado como terra roxa estruturada (Alfisol), série Luiz de Queiroz.

\subsection{Preparação da área experimental}

O trabalho foi realizado em 6 plantas (três plantas para abertura de trincheira e três para monitoramento da umidade) de um pomar de 1 hectare de mangueira (Mangifera indica L.), cultivar Hadem, enxertada com um porta enxerto da variedade Carlota, com 5 anos de idade, em espaçamento de $10 \times 10$ metros, irrigadas sob microaspersão. Nesta área foram abertas 3 trincheiras uma em cada planta das três 
selecionadas (Figura 11a), com auxilio de uma retro-escavadeira, até a profundidade de 1,80 metros a partir da superficie do solo, e 6,0 metros de comprimento (sendo três metros para o lado esquerdo e três para o lado direito em relação ao tronco da planta) e 1,50 metros de largura, distante do tronco da planta $0,50 \mathrm{~m}$. Nestas trincheiras, foram coletadas amostras de solo deformadas e indeformadas as profundidades de $0-0,20 ; 0,20-$ 0,$40 ; 0,40-0,60 ; 0,60-0,80 ; 0,80-1,00 ; 1,00-1,20$ metros para obtenção das características fisico-químicas (Embrapa, 1979). Na tabela 01, encontra-se a composição granulométrica da área.

Tabela 1. Composição granulométrica e densidade global da área experimental.

\begin{tabular}{ccccc}
\hline $\begin{array}{c}\text { Profundidade } \\
\cdots--\mathrm{m}-\cdots\end{array}$ & Areia & $\begin{array}{c}\text { Silte } \\
\%\end{array}$ & $\begin{array}{c}\text { Argila } \\
\text { - }\end{array}$ & $\begin{array}{c}\text { Densidade } \\
-\cdots\end{array}$ \\
\hline $00-0,20$ & 31,49 & 27,64 & 40,87 & 1,54 \\
$0,20-0,40$ & 29,23 & 23,16 & 47,62 & 1,51 \\
$0,40-0,60$ & 26,17 & 23,53 & 50,30 & 1,36 \\
$0,60-0,80$ & 23,98 & 23,16 & 52,85 & 1,41 \\
$0,80-1,00$ & 31,49 & 34,38 & 34,13 & 1,39 \\
$1,00-1,20$ & 25,33 & 27,26 & 47,41 & 1,13 \\
\hline
\end{tabular}

A eliminação das ervas daninhas próximas as plantas foi realizada por meio de capina com enxada até a distância de 3,0 metros, 20 dias antes da preparação da trincheira.

O sistema radicular foi estudado em plantas com diâmetro de copa médio do pomar aproximadamente 5 metros. Após abertura das trincheiras foi realizada a exposição das raizes por meio de lavagem com água de tal forma que a parede da trincheira permanecesse em nivel com vertical e a uma distância do tronco da planta de 20 centímetros, permitindo assim a pintura localizada das raízes, com tinta spray de coloração branca, visando aumentar o contraste em relação ao solo. Em seguida realizouse o corte das raízes que se apresentavam na horizontal para fora do perfil do solo 
deixando-as com apenas $1 \mathrm{~cm}$ de comprimento. A diferenciação das raízes de outras espécies foi feita através da coloração e ramificação. Após a secagem da tinta realizou-se o umidecimento do perfil com uma piceta e com auxilio de uma espátula, a retirada da tinta excedente do solo.

Utilizou-se de uma tela nas seguintes dimensões: $5,00 \mathrm{~m} \mathrm{x} \mathrm{1,25} \mathrm{m,} \mathrm{com}$ quadrículas de 0,25 por 0,25 metros $\left(0,0625 \mathrm{~m}^{2}\right)$ totalizando 100 quadrículas por planta, feitas com barbante pintado de azul anil, com intuito de evitar o reflexo no momento da filmagem. Para identificação das quadrículas foram utilizadas plaquetas numeradas de cartolina, onde o número 1 situou-se na quadrícula superior do lado direito. No lado esquerdo, a quadrícula superior tinha o número 1', como mostra a Figura 2.

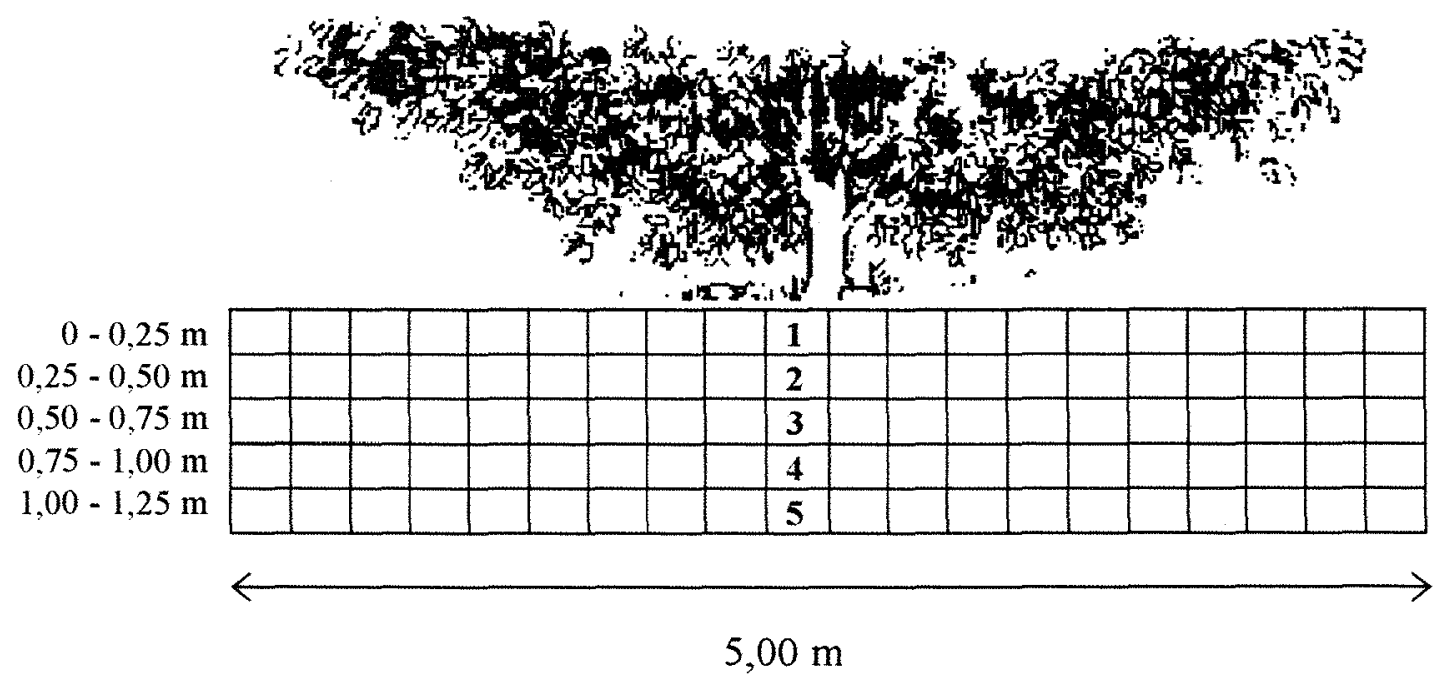

Figura 2 - Esquema experimental de amostragem utilizado para quantificação da distribuição radícular através da filmagem. Disposição da tela junta a planta de manga e dimensões da tela. 


\subsection{Obtenção e digitalização das imagens}

A filmagem foi realizada com filmadora de vídeo comum, a uma distância de aproximadamente 1 metro do perfil durante o periodo da manhã, visto que, durante o periodo da tarde havia a incidência direta do sol sobre o perfil, impossibilitando a filmagem devido a formação de sombra e reflexo por parte do perfil do solo.

As imagens obtidas de cada quadrícula foram digitalizadas utilizando-se em uma placa digitalizadora acoplada a um microcomputador, com resolução espacial igual a 512 × 512 pixels e 256 tons de cinzas por "pixel".

O trabalho de digitalização das imagens foi realizado no Departamento de Engenharia Rural da ESALQ/USP.

Após a digitalização, as imagens foram transferidas para o programa COREL DRAW, com o objetivo de variar o contraste, brilho, corrigir distorções das imagens, transformando-as em escala de tons cinza ( 8 bit), como mostra a Figura 3.

O processamento das imagens foi realizado por meio do "software" SIARCS ( Sistema Integrado para Análise de Raízes e Cobertura do Solo), desenvolvido pela EMBRAPA CNPDIA - São Carlos - SP (Crestana et al. 1994), locado no Departamento de Física do Solo do CENA (Centro de Energia Nuclear na Agricultura).

Este programa permitiu avaliar a distribuição do sistema radícular da mangueira quanto a percentagem de área e ao comprimento das raizes.

As imagens digitalizadas e tratadas no CORELDRAW, foram abertas no SIARCS para serem analisadas. Inicialmente as imagens foram submetidas à seleção da área e uma posterior calibração, a qual constituiu da dimensão das quadrículas ou seja $0,25 \times 0,25 \mathrm{~m}$, afim de poder-se relacionar um comprimento conhecido com o numero de "pixels" correspondente a esta área (Figura. 4). 

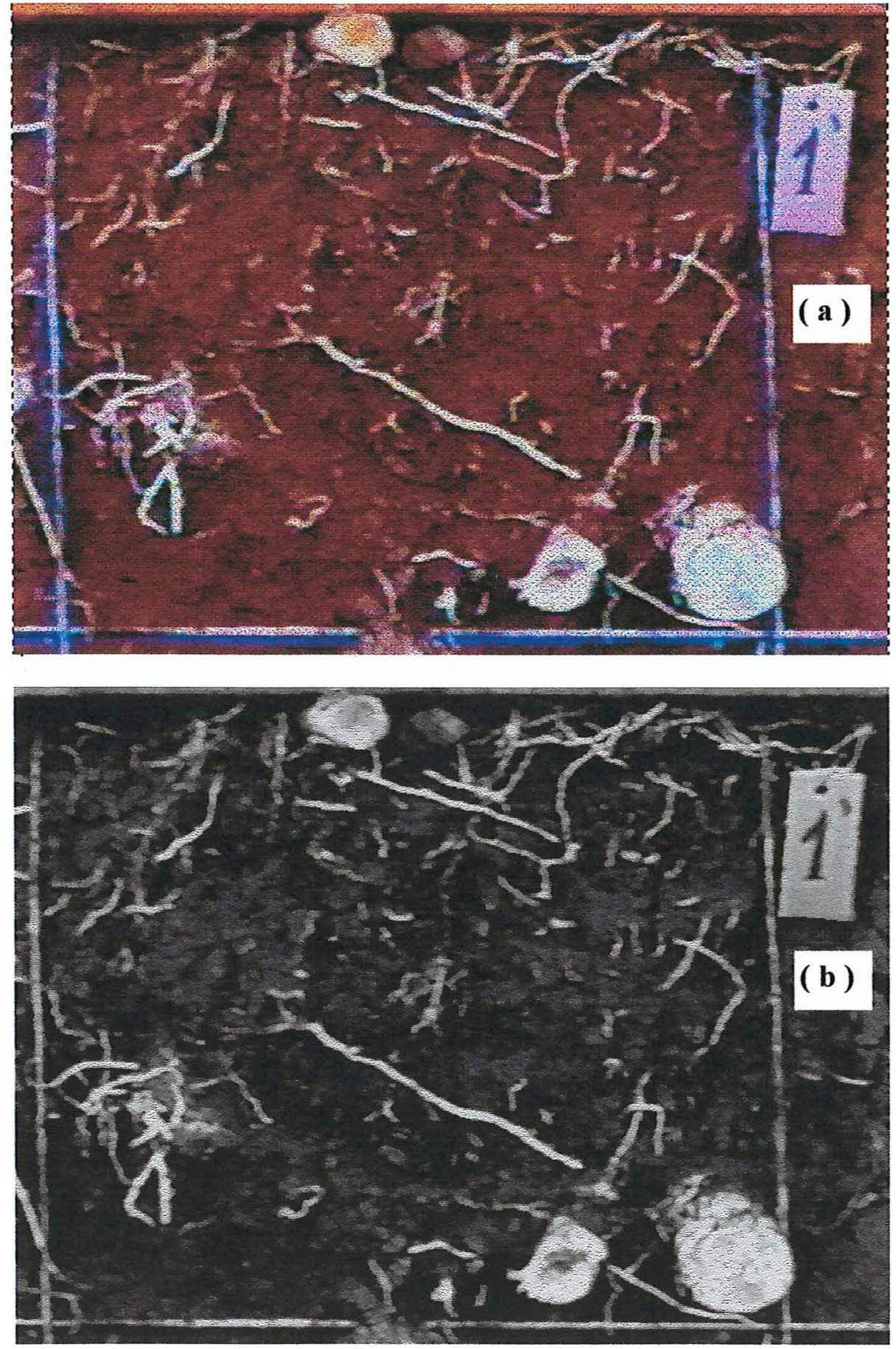

Figura 3 -(a) Imagem digitalizada e tratada (contrąste e brilho) no CORELDRAW, (b) Imagem transformada no CORELDRAW em: Grayscale 8 bits. 


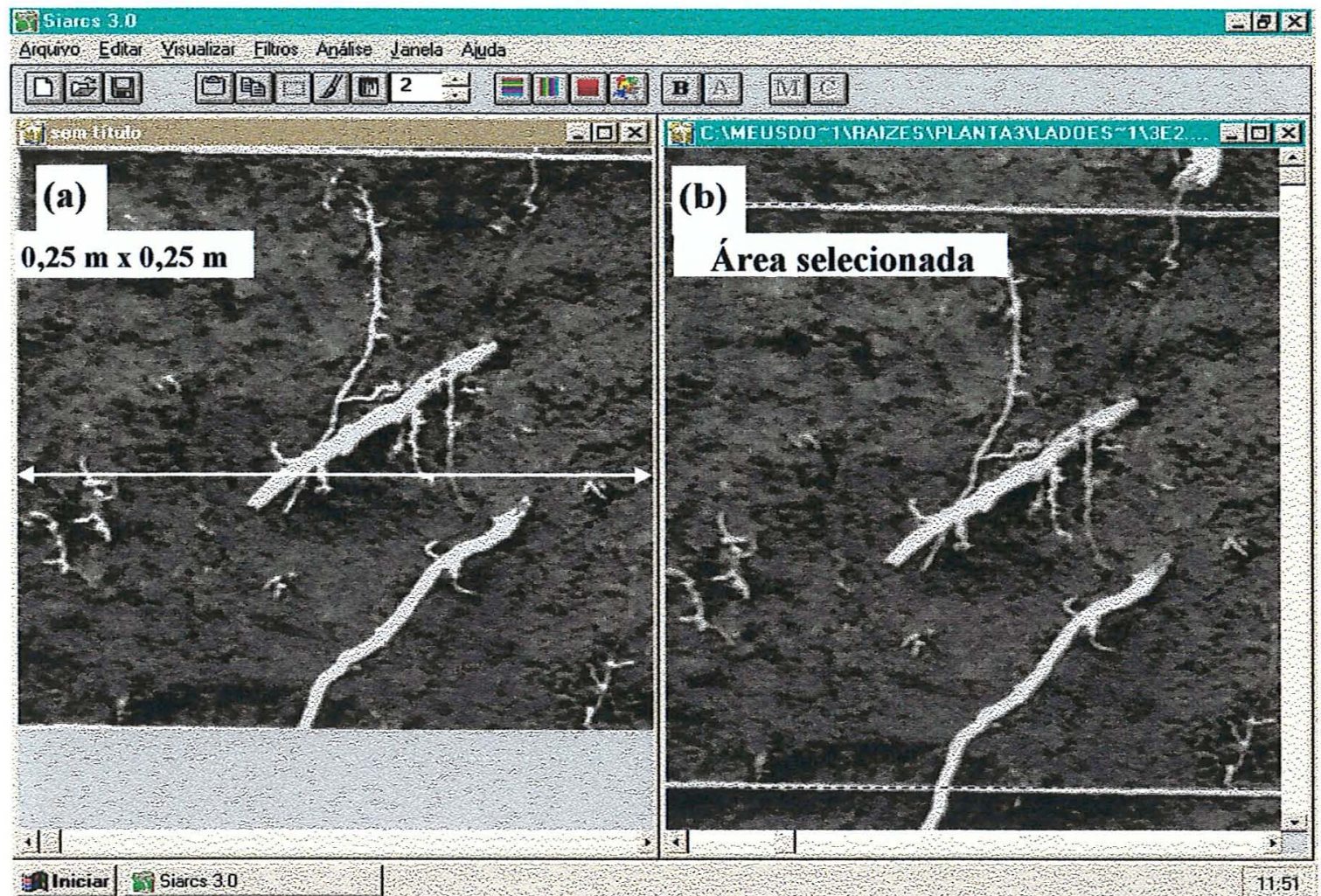

Figura 4 - (a) Imagem calibrada nas dimensões da quadrícula, (b) Seleção da área da quadrícula $(0,25 \mathrm{~m} \times 0,25 \mathrm{~m})$.

Em seguida foi realizada a seleção das raízes por meio do filtro TRESHOLDING, presente no SIARCS, através da cor cinza em 256 tons. Após selecionadas e corrigidas as distorções da imagem efetuou-se a pintura das raízes afim de obter uma boa identificação na tela do computador (Figura 5).

A fase seguinte foi a "binarização" que consiste da transformação dos 256 tons cinza em apenas dois: preto e branco, permitindo assim a identificação dos pixels que representam as raízes em preto e o restante da imagem em branco (Figura 6).

A fase de quantificação da imagem foi feita por meio de um levantamento de seu histograma, que é a freqüência das regiões claras e escuras em uma imagem. Assim, o cálculo da densidade de raízes foi feito dividindo-se o número de "pixels" correspondente às raízes (em preto) pelo número total de "pixels" da imagem. 
O resultado final foi expresso em densidade de raízes presentes em 625 $\mathrm{cm}^{2}(25 \mathrm{~cm} \times 25 \mathrm{~cm})$ de solo.

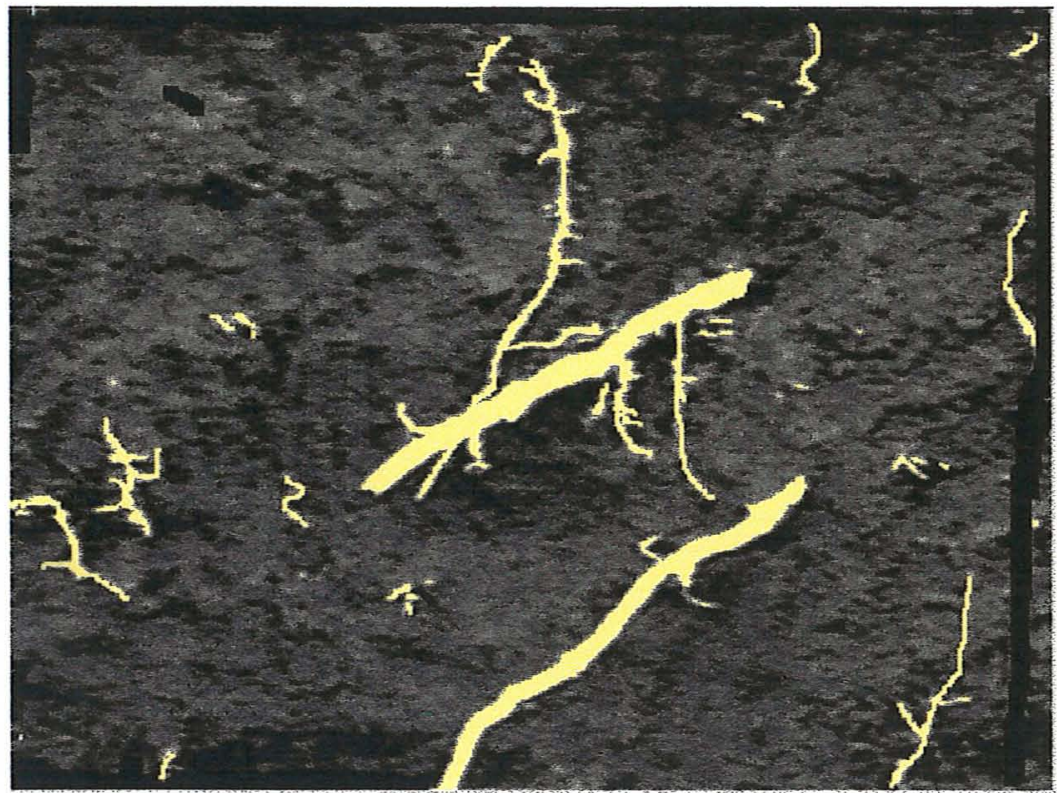

Figura 5 - Imagem pintada para diferenciar as raízes do solo.

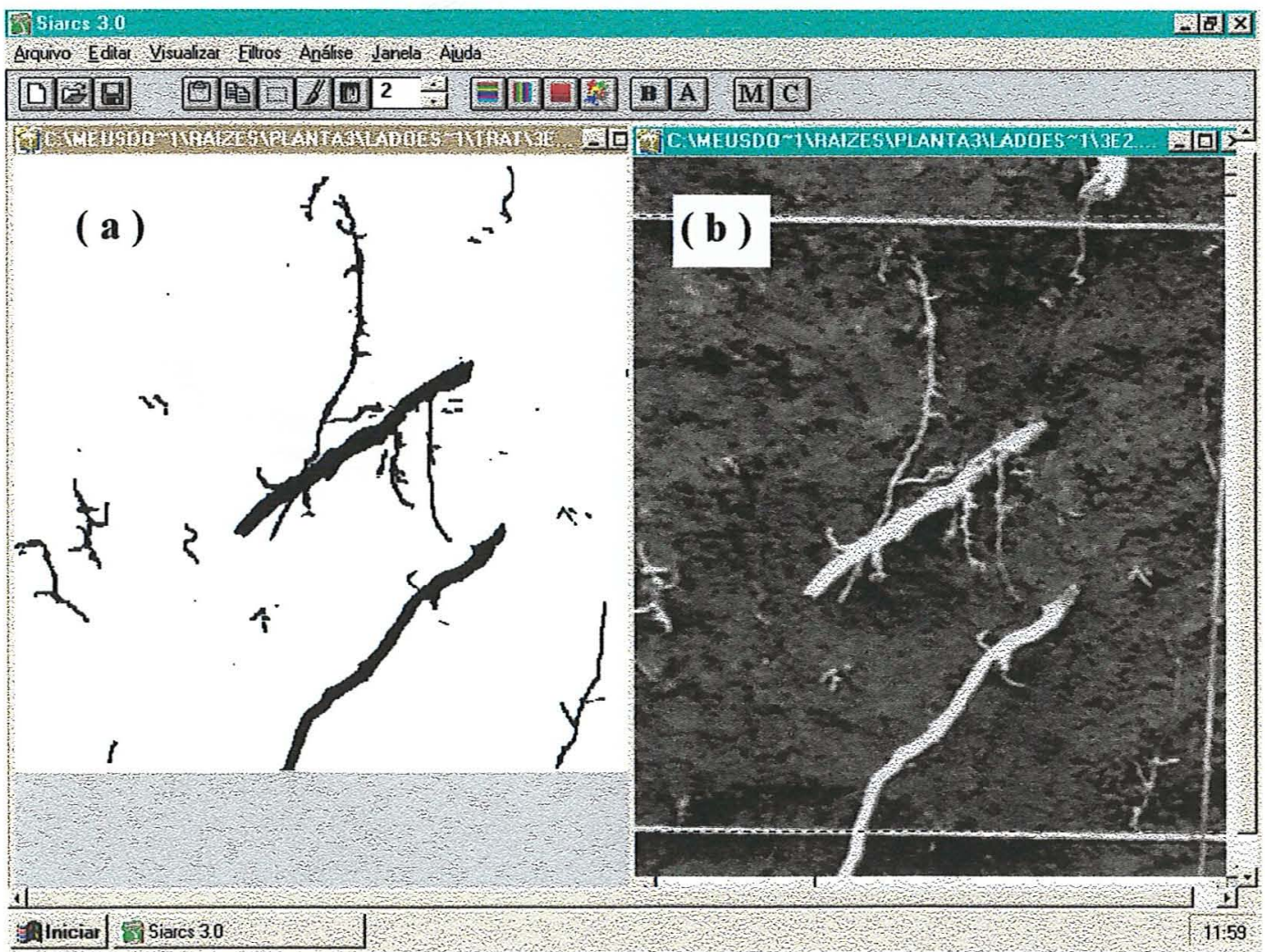

Figura 6 - (a) Imagem "binarizada", (b) imagem das raízes antes da pintura. 
Outra maneira utilizada na mensuração do sistema radicular foi o comprimento total em $625 \mathrm{~cm}^{2}$ de solo. Para tanto, utilizou-se do processo de esqueletonização de raízes, que consiste em transformar as raízes com mais de um pixel de largura em apenas larguras de apenas um pixel. Contabilizando os pixels pretos restantes da imagem obtém-se o comprimento radicular presente na área (Figura 7).

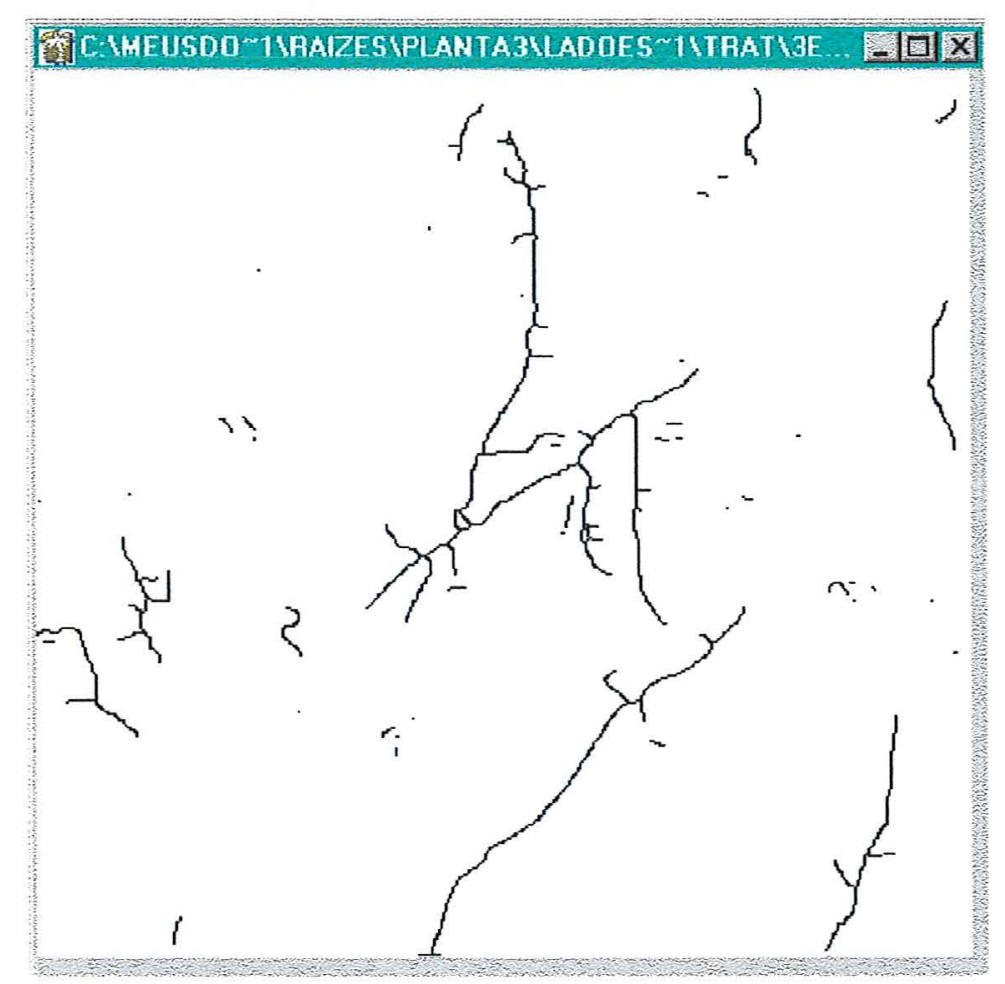

Figura 7 - Imagem esqueletonizada ou seja afinamento de raízes.

\subsection{Delineamento Estatístico para estudo da distribuição do sistema radicular.}

O esquema da análise da variância para as variáveis densidade e comprimento de raiz foi o delineamento em blocos ao acaso, com disposição dos tratamentos (distância e profundidade) em faixas, ver Tabela 2. 
Tabela 2. Quadro da análise de variância

\begin{tabular}{lcc}
\hline Causas da variação & G.L & F \\
\hline Blocos & 5 & QM Dist./ QM Bl x Dist \\
Distância & 9 & \\
Blocos x Distância & 45 & QM Prof./ QM B1 x Prof. \\
Profundidade & 4 & \\
Blocos x Profundidade & 20 & QM D x P/ QM Resíduo \\
Distância x Profundidade & 36 & \\
Resíduo & 180 & \\
\hline Total & 299 &
\end{tabular}

\subsection{Cálculo do balanço hídrico com tensiômetros.}

O balanço hídrico da cultura foi realizado em três plantas com a mesma conformação de copa, segundo a forma descrita por Reichardt (1990)

$$
\mathrm{P}+\mathrm{I}-\mathrm{ET}-\mathrm{RO}-\mathrm{DP}+\mathrm{AC}=\Delta \mathrm{A}_{\mathrm{L}}
$$

onde:

$$
\begin{aligned}
\mathrm{P} & =\text { precipitação }(\mathrm{mm}) \\
\mathrm{I} & =\text { irrigação }(\mathrm{mm}) \\
\mathrm{ET} & =\text { evapotranspiração }(\mathrm{mm} / \mathrm{dia}) \\
\mathrm{RO} & =\text { escoamento superficial }(\mathrm{mm}) \\
\mathrm{DP} & =\text { drenagem profunda }(\mathrm{mm}) \\
\mathrm{AC} & =\text { ascensão capilar }(\mathrm{mm}), \mathrm{e} \\
\Delta \mathrm{A}_{\mathrm{L}} & =\text { Variação de armazenamento de água no volume de solo considerado }(\mathrm{mm})
\end{aligned}
$$

Foram instalados 40 tensiômetros por planta num total de 3 plantas distribuídos em quatro baterias às distâncias de $50,100,150$ e $200 \mathrm{~cm}$ do tronco da planta às profundidades de $10,20,30,40,60,70,80,90$ e 100 centímetros distribuídos no sentido anti-horário (Figura $8 ; 11 \mathrm{~b} ; 11 \mathrm{c}$ ), com o objetivo de medir a variação de umidade do solo por meio das curvas de retenção. Estas foram determinadas a cada 20 
$\mathrm{cm}$ de profundidade até $120 \mathrm{~cm}$, com amostras indeformadas, por dessorção, com o auxílio de uma mesa de tensão e por câmaras de pressão de Richards com placa porosa. As amostras foram submetidas as tensões de; 0,$1 ; 1 ; 2 ; 4 ; 10 ; 30 ; 50 ; 100 ; 500$ e 1500 Kpa. Para facilitar a conversão dos dados do potencial matricial da água no solo em unidade volumétrica utilizou-se o modelo de ajuste da curva de retenção proposta por van Genüchten (1980) Equação (4). A umidade a 10 e a $20 \mathrm{~cm}$, foi calculada pela curva de retenção que representava a profundidade de $0-20 \mathrm{~cm}$, a umidade a 30 e $40 \mathrm{~cm}$ pela curva de 20-40 e assim sucessivamente para as demais profundidades.

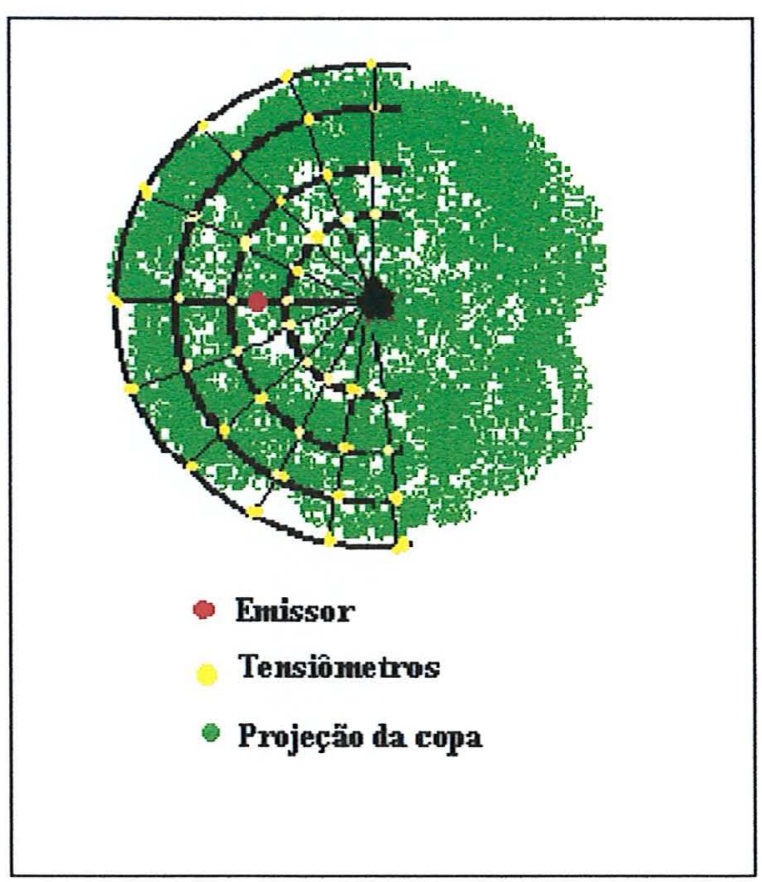

Figura 8 - Vista em planta da disposição dos tensiômetros e do emissor de irrigação em relação ao tronco da planta.

Durante o período não houve chuva, conforme Figura 9, irrigação e a drenagem profunda e ascensão capilar pôde ser desprezada com segurança, haja vista que se analizava a zona radicular, resumindo a Equação (2) à Equação (3)

$$
\mathrm{ET}=-\Delta \mathrm{A}_{\mathrm{L}}
$$




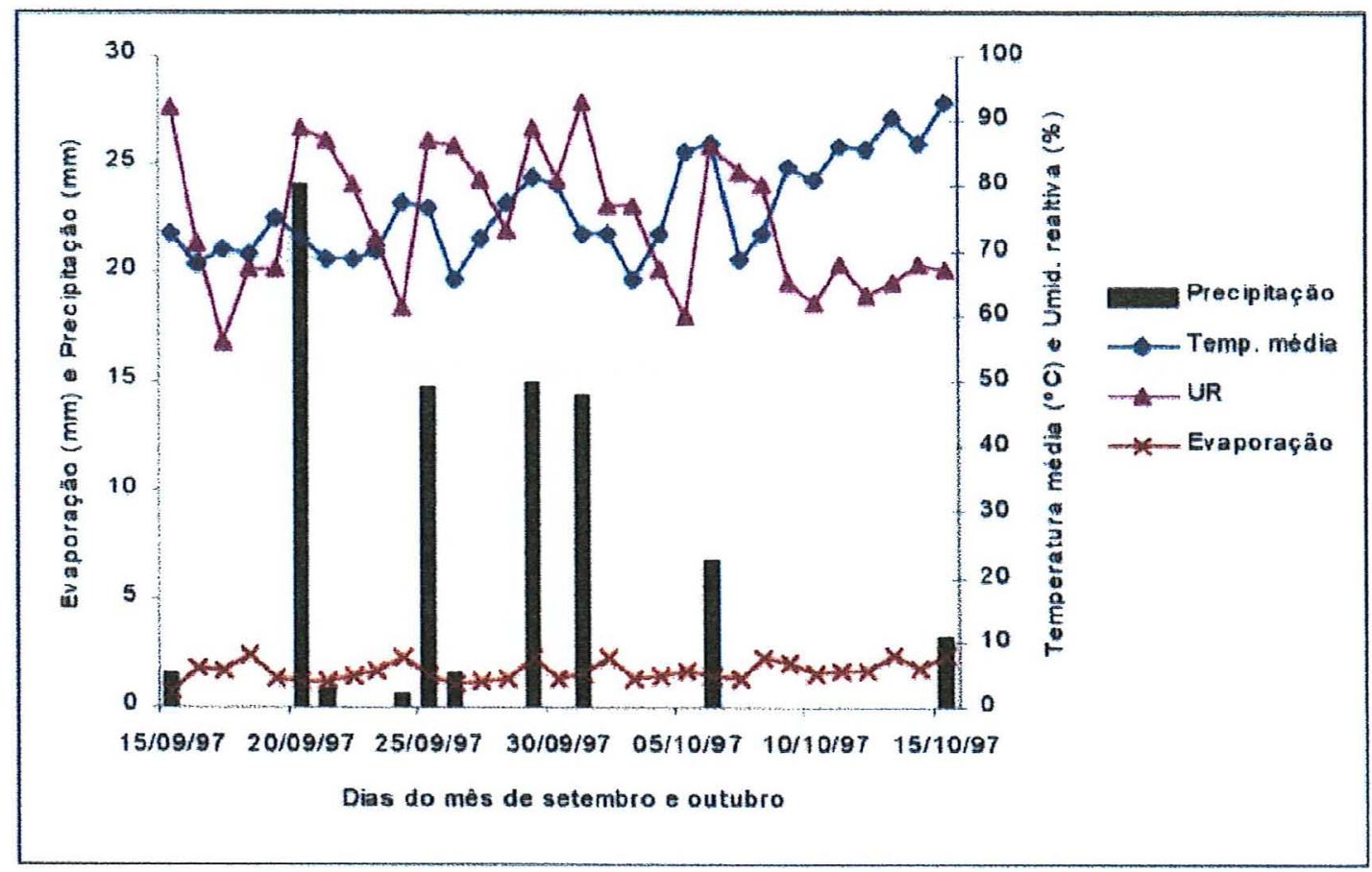

Figura 9 - Dados climáticos do período da avaliação.

As leituras dos tensiômetros foram realizadas a cada 24 horas, durante o período da manhã, tensiômetro digital de punção, que fornecia as leituras do potencial matricial em milibar (mbar). As quais eram convertidas em $\mathrm{cm}$ de coluna de água para serem e utilizadas na Equação (4) para estimar a umidade do solo.

$$
\theta=\theta r+\frac{\theta s-\theta r}{\left[1+(\alpha|\phi m|)^{n}\right]^{m}}
$$

onde $\theta \mathrm{s}$ e $\theta \mathrm{r}$ são umidade volumétrica de saturação e residual, respectivamente, $\phi \mathrm{m}$ potencial matricial e $\alpha$, m e n são constantes empíricas, na Tabela (3) estão representados os valores desses coeficientes para as diversas profundidades .

O calculo da variação de armazenamento do período foi obtido com dados médios de umidade das três plantas para cada camada e distância em relação ao tronco da planta, empregando a Equação (5).

$$
\Delta \mathrm{A}=(\theta \mathrm{f}-\theta \mathrm{i}) \cdot \mathrm{Z}
$$


onde :

$\Delta \mathrm{A}=$ Variação do armazenamento de água na camada de solo correspondente a efetividade radicular.

$\theta \mathrm{i}=$ Umidade média inicial $\left(\mathrm{cm}^{3}\right.$ de água $/ \mathrm{cm}^{3}$ de solo $)$

$\theta f=$ Umidade média final $\left(\mathrm{cm}^{3}\right.$ de água/ $\mathrm{cm}^{3}$ de solo)

$\mathrm{Z}=$ Espessura da camada $(\mathrm{mm})$

Tabela 3. Valores de $n, m, \theta s, \theta r$ e $\alpha$ da curva de retenção de água no solo para as diversas profundidades.

\begin{tabular}{|c|c|c|c|c|c|}
\hline \multirow{2}{*}{$\begin{array}{l}\text { Profundidade } \\
\text { (m) }\end{array}$} & \multirow[t]{2}{*}{$\mathrm{n}$} & \multirow[t]{2}{*}{$\mathrm{M}$} & $\theta s$ & $\theta r$ & \multirow[t]{2}{*}{$\alpha$} \\
\hline & & & \multicolumn{2}{|c|}{$\mathrm{cm}^{3} / \mathrm{cm}^{3}$} & \\
\hline 0,20 & 1,2809 & 0,2193 & 0,474 & 0,301 & 0,1802 \\
\hline 0,40 & 1,1492 & 0,1298 & 0,479 & 0,266 & 0,2216 \\
\hline 0,60 & 1,3372 & 0,2522 & 0,513 & 0,342 & 0,1497 \\
\hline 0,80 & 1,1289 & 0,1142 & 0,503 & 0,225 & 0,1271 \\
\hline 1,00 & 1,0983 & 0,0895 & 0,543 & 0,180 & 0,5299 \\
\hline 1,20 & 1,4143 & 0,2929 & 0,554 & 0,256 & 0,1117 \\
\hline
\end{tabular}

A estimativa da atividade radicular foi calculada através da razão da evapotranspiração da camada pelo somatório de todas as evapotranspirações das camadas consideradas, Equação (6).

$$
\operatorname{EArad}(\%)=\frac{E T c a m}{\sum E T c a m} \times 100
$$

onde:

EArad $(\%)=$ estimativa da atividade radicular

ET cam = Evapotranspiração da camada $(\mathrm{mm} / \mathrm{dia})$

$\Sigma$ Etcam = Somatório de total as evapotranpirações das camadas consideradas ( $\mathrm{mm} / \mathrm{dia})$

O consumo em litros por camada foi obtido multiplicando-se a evapotranspiração $(\mathrm{mm} / \mathrm{dia})$ pela área que cada bateria de tensiômetro representava. As áreas das baterias 1, 2, 3 e 4 foram calculadas da seguinte forma: 
Área da Bateria $1\left(\mathrm{AB}_{1}\right)=\pi\left(\mathrm{R}_{1}\right)^{2} / 2$

Área da Bateria $2\left(\mathrm{AB}_{2}\right)=\pi\left(\mathrm{R}_{2}\right)^{2} / 2-\mathrm{AB}_{1}$

Área da Bateria $3\left(\mathrm{AB}_{3}\right)=\pi\left(\mathrm{R}_{3}\right)^{2} / 2-\left(\mathrm{AB}_{1}+\mathrm{AB}_{2}\right)$

Área da Bateria $4\left(\mathrm{AB}_{4}\right)=\pi\left(\mathrm{R}_{4}\right)^{2} / 2-\left(\mathrm{AB}_{1}+\mathrm{AB}_{2}+\mathrm{AB}_{3}\right)$

resultando os respectivos valores $0,785 \mathrm{~m}^{2}, 2,35 \mathrm{~m}^{2}, 3,93 \mathrm{~m}^{2}, 5,50 \mathrm{~m}^{2}$ (Figura 10); sendo $R_{1}, R_{2}, R_{3}$ e $R_{4}$ distâncias da bateria em relação ao tronco da planta.

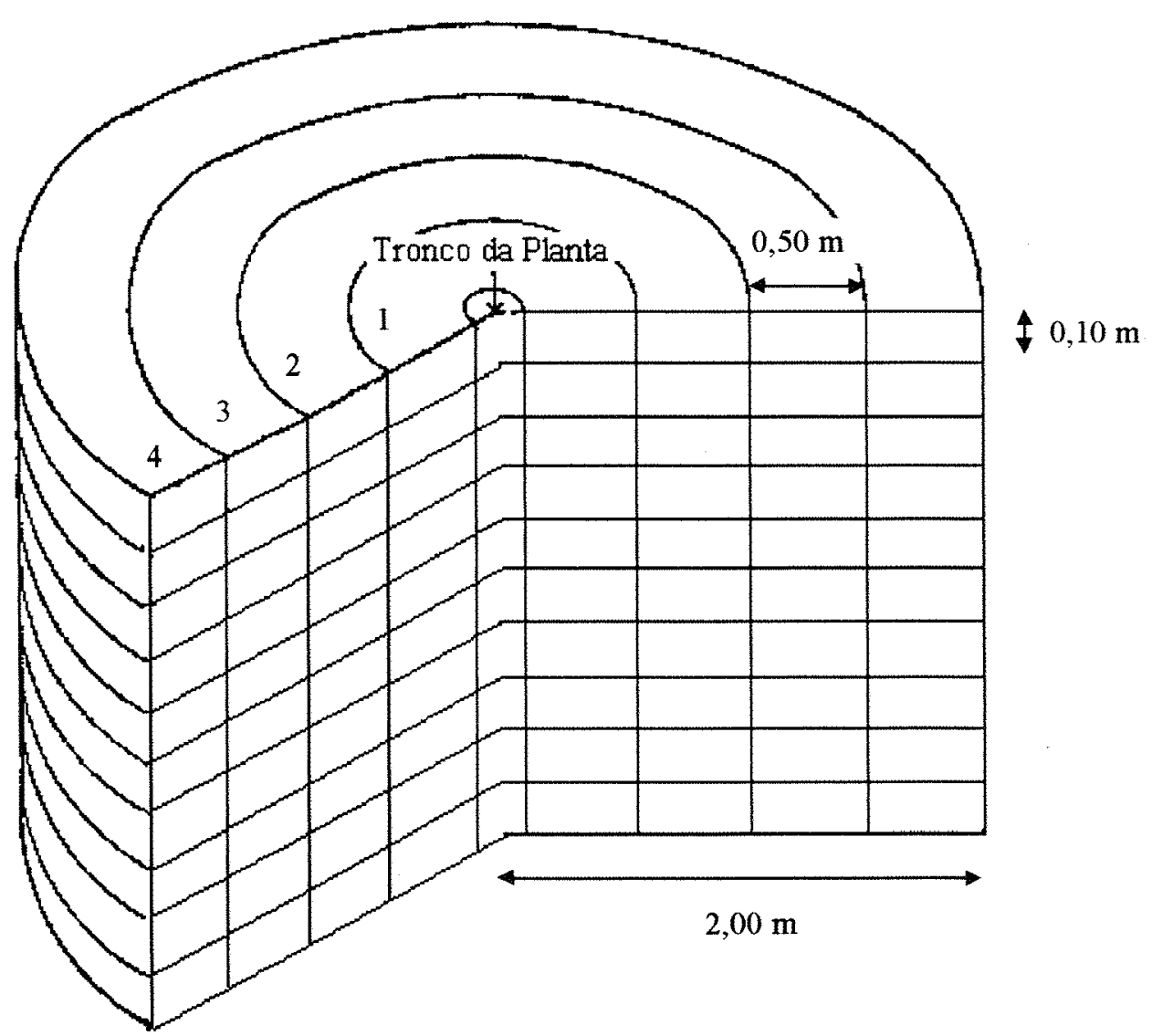

Figura 10: Esquema dos anéis concêntricos utilizados na quantificação do volume de água extraído pelo sistema radicular, a partir da variação de lâmina pontual na perfil. 

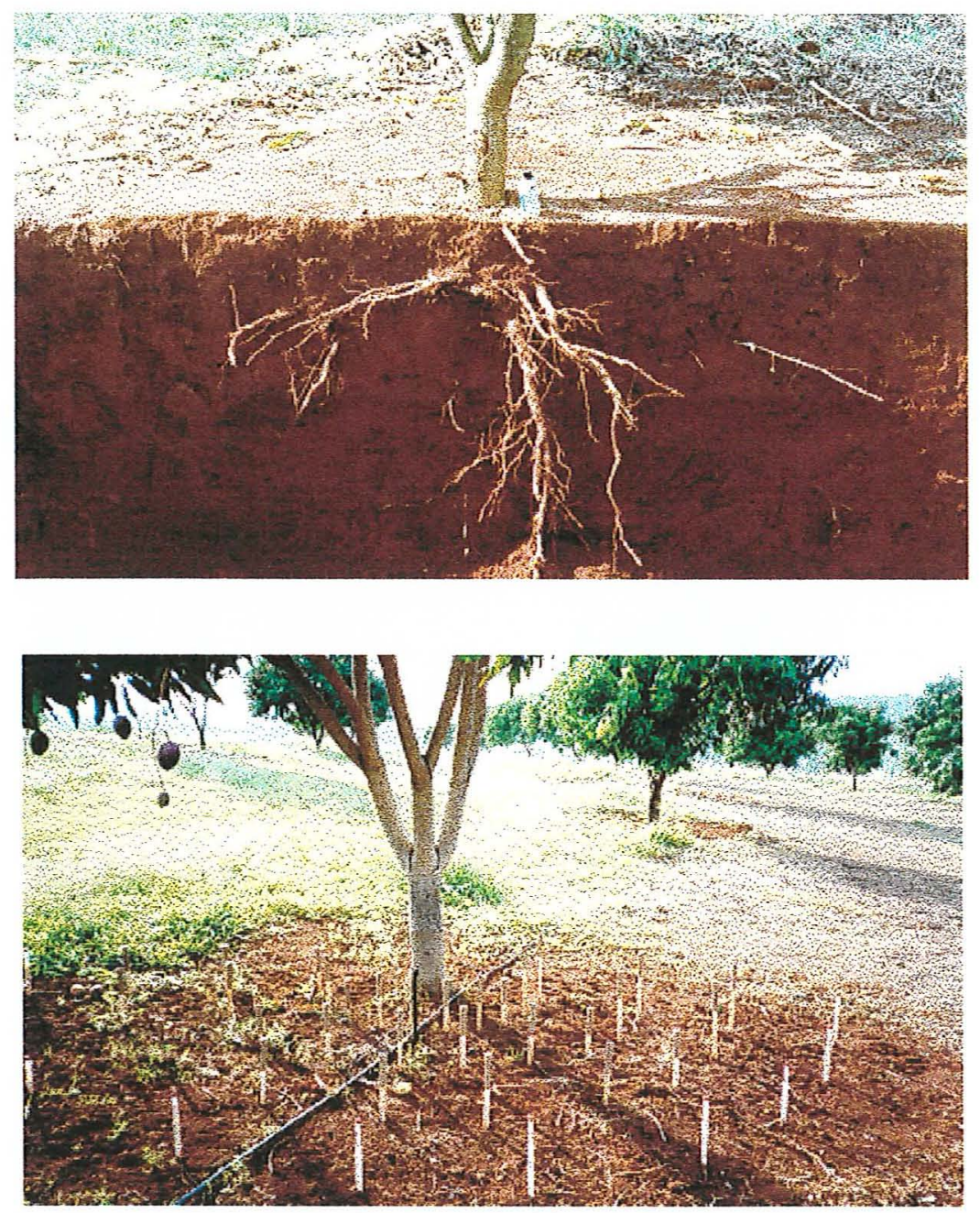

(b)

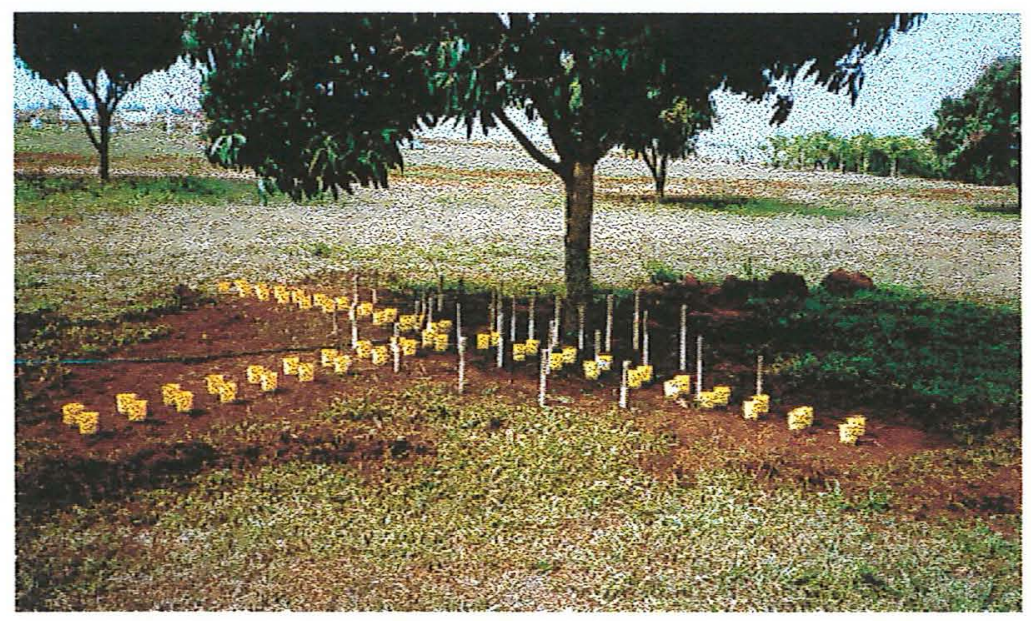

(c)

Figura 11. (a) Exposição do sistema radicular; (b) Disposição dos tensiômetros junto à planta; (c) Ensaio do perfil de distribuição do emissor. 


\section{Resultados e Discussão}

\subsection{Análise estatística.}

A análise exploratória dos dados, para as variáveis densidade e comprimento de raiz, mostrou heterogeneidade nos dados dos tratamentos distância e profundidade. $\mathrm{O}$ estudo da heterocedasticidade (homogeneidade de variância), entre às médias e variâncias, indicou uma transformação do tipo $\sqrt{X+0,5}$ pará área $\mathrm{e}$ comprimento de raiz.

A análise estatística dos dados para essas variáveis, Tabela 4, mostra que houve diferença significativa para profundidade e distância. No estudo da interação profundidade/distância, houve diferença significativa para ambas as variáveis .

Tabela 4. Análise da variância dos dados transformados referentes às variáveis densidade e comprimento de raízes.

\begin{tabular}{cccc}
\hline Causas de variação & G L & \multicolumn{2}{c}{ Q M } \\
\cline { 3 - 4 } & & Densidade & Comprimento \\
\hline Blocos & 5 & & \\
Distância & 9 & $66,56618^{* *}$ & $296,46459^{* *}$ \\
Profundidade & 4 & $31,92801^{* *}$ & $96,78654^{* *}$ \\
Distância x Profundidade & 36 & $3,72744^{* *}$ & $9,95582^{* *}$ \\
Resíduo & 180 & 1,56839 & 4,99297 \\
\hline Total & 299 & &
\end{tabular}

** significativo pelo teste $\mathrm{F}$, a nivel de $1 \%$ 
Dado que a interação profundidade $\mathrm{x}$ distância foi significativo, efetuou-se um estudo das distâncias nas profundidades e das profundidades nas distâncias para detectar qual ou quais combinações explicavam melhor o comportamento das variáveis comprimento e densidade de raiz.

Verifica-se por meio da Tabela 5, que o ponto onde apresenta o mínimo de comprimento de raiz, na camada de $0-0,25 \mathrm{~m}$ de profundidade, encontra-se a 184,52 $\mathrm{cm}$ em relação ao tronco da planta, com um valor estimado em $7 \times 10^{-3} \mathrm{~cm}$ de raiz/ $\mathrm{cm}^{2}$ de solo, sendo este local uma referência onde não se deve fazer uso de adubação nem instalar instrumentos para monitoramento da irrigação.

Observa-se que, tanto para a profundidade dentro das distâncias quanto o inverso (Tabelas 5 e 6), as regressões polinomiais que descrevem o comportamento das variáveis densidade e comprimento de raiz são equações lineares decrescentes, mostrando assim que, à medida que distanciamos do tronco da planta a densidade e o comprimento das raízes diminuem, assim como, à medida que aprofundamos no perfil do solo essas variáveis também diminuem.

Tabela 5. Regressões polinomiais significativas dos dados transformados da distância dentro da profundidade e da profundidade dentro das distâncias com os seus respectivos coeficientes de determinação $\left(\mathrm{R}^{2}\right)$ para a variável comprimento de raiz ( $\mathrm{cm}$ de raiz/ $\mathrm{cm}^{2}$ de solo).

\begin{tabular}{llll}
\hline Prof. / Dist. (cm) & Equações & $\mathrm{R}^{2}(\%)$ & Máx./Min \\
\hline P - 0,25 & $\mathrm{Y}=19,25727-0,15886 \mathrm{X}+0,00043 \mathrm{X}^{2}$ & 80,82 & 184,52 \\
P - 1,00 & $\mathrm{Y}=10,50831-0,02595068 \mathrm{X}$ & 56,23 & \\
P - 1,25 & $\mathrm{Y}=7,66845-0,0231316 \mathrm{X}$ & 51,04 & \\
D - 0,25 & $\mathrm{Y}=18,45519-0,0658056 \mathrm{X}$ & 93,26 & \\
D - 0,50 & $\mathrm{Y}=11,470055-0,049777 \mathrm{X}$ & 74,48 & \\
D - 1,00 & $\mathrm{Y}=8,393925-0,037307 \mathrm{X}$ & 69,78 & \\
D - 1,25 & $\mathrm{Y}=8,988758-0,0314856 \mathrm{X}$ & 70,05 & \\
D - 2,25 & $\mathrm{Y}=10,641384-0,050518 X$ & 79,50 & \\
\hline
\end{tabular}


Tabela 6. Regressões polinomiais significativas dos dados transformados da distância dentro da profundidade e da profundidade dentro das distâncias com os seus respectivos coeficientes de determinação $\left(\mathrm{R}^{2}\right)$ para a variável densidade de raiz ( $\mathrm{cm}^{2}$ de raiz $/ \mathrm{cm}^{2}$ de solo).

\begin{tabular}{lcll}
\hline Prof. / Dist. (cm) & \multicolumn{1}{c}{ Equações } & $\mathrm{R}^{2}(\%)$ & Máx./ Min \\
\hline P - 1,00 & $\mathrm{Y}=4,745055-0,0123601 \mathrm{X}$ & 58,79 \\
P - 1,25 & $\mathrm{Y}=3,481271-0,0955331 \mathrm{X}$ & 50,19 \\
D - 0,25 & $\mathrm{Y}=10,324196-0,050035 \mathrm{X}$ & 88,76 \\
D - 0,50 & $\mathrm{Y}=4,990605-0,0206334 \mathrm{X}$ & 72,65 \\
D - 0,75 & $\mathrm{Y}=6,041626-0,0200975 \mathrm{X}$ & 92,38 \\
D - 1,25 & $\mathrm{Y}=4,39904-0,017761 \mathrm{X}$ & 78,49 & \\
D - 2,25 & $\mathrm{Y}=6,019814-0,034608 \mathrm{X}$ & 99,23 & \\
\hline
\end{tabular}

\subsection{Distribuição horizontal e vertical das raízes.}

\subsubsection{Comprimento de raiz}

Verifica-se por meio da Figura 13a que $86,5 \%$ do comprimento total de raiz encontra-se até a distância de $175 \mathrm{~cm}$ do tronco da planta. Sendo este o limite máximo para se instalar e monitorar a irrigação, assim como para se fazer uso de práticas de adubação, uma vez que a assimilação de fertilizantes por parte da planta apresenta-se relacionada com a máxima quantidade de raízes ativas envolvidas no processo. Os resultados referentes ao comprimento do sistema radicular em função da profundidade (Figura 13b) mostram que a maior quantidade encontra-se na camada superficial com $26,8 \%$ nos primeiros $25 \mathrm{~cm}$ de profundidade do solo, e atingindo $70,0 \%$ nos $75 \mathrm{~cm}$ de profundidade.

Esses dados estão de acordo com os encontrados por Bojappa \& Singh (1973), onde verificaram que a maior concentração radicular encontrava-se a $60 \mathrm{~cm}$ de profundidade e $120 \mathrm{~cm}$ de distância do tronco. E também com os encontrados por Rojas 
(1989), que analisando a distribuição de raizes de cultivares de mangueira, pelo método do trado, observou que a maior a concentração das radicelas estavam nas camadas superficiais, existindo aproximadamente $46,77 \%$ nos primeiros $30 \mathrm{~cm}$ do solo e $70,58 \%$ até os $60 \mathrm{~cm}$ de profundidade e na distribuição horizontal a maior concentração das radicelas encontravam-se a 100 e $200 \mathrm{~cm}$ de distância de tronco, com 35,27\% e $25,89 \%$, respectivamente.

\subsubsection{Densidade de raiz}

Verifica-se que cerca de $74,6 \%$ do sistema radicular encontra-se até 150 $\mathrm{cm}$ do tronco da planta, na faixa horizontal $73,8 \%$ em profundidade até $75 \mathrm{~cm}$, para a variável densidade de raiz (Figura 13c e 13d). Estes dados estão de acordo com os obtidos por Choudhury \& Soares (1992), que em estudo realizado com a variedade Tommy Atkins, utilizando o método monolítico, observaram que $68 \%$ das raizes de absorção e $86 \%$ das raizes de sustentação estavam localizadas na faixa horizontal de 90 a $260 \mathrm{~cm}$ em relação ao tronco da planta. $\mathrm{Na}$ faixa vertical $65 \%$ das raizes de absorção e $56 \%$ das de sustentação ocorrem na profundidade do solo de 0 a $60 \mathrm{~cm}$. E também, com os dados obtidos por Ávilan \& Meneses (1979), estudando a variedade Hadem, pelo método da trincheira, observaram que a maior concentração de raízes ocorreram lateralmente a $150 \mathrm{~cm}$ do caule e variando de acordo com o perfil do solo.

A Figuras $12 \mathrm{a}$ e $12 \mathrm{~b}$ mostram o comportamento do comprimento de raiz e da densidade em função da distância e da profundidade, ao analisarmos conjuntamente as duas figuras, nota-se que para a distância de $75 \mathrm{~cm}$ na Figura $12 \mathrm{~b}$, ocorre um certo distanciamento da camada $0-25$, para com as camadas $25-50,50-75,75-100$, o que não observamos na Figura 12a, isto deve-se ao fato da camada de 0-25 possuir raizes com diâmetros superior as demais camadas, haja visto que o processo de esqueletonização tornam todas as raízes com mesmo diâmetro permitindo assim fazer essas inferências.

Observa-se também que nas distâncias de 150 e $175 \mathrm{~cm}$ na camada de 0 25 apresenta uma densidade entorno de $2,0 \times 10^{-2} \mathrm{~cm}^{2}$ de raiz/ $\mathrm{cm}^{2}$ de solo e $1,0 \times 10^{-2}$ 
$\mathrm{cm}^{2}$ de raiz $/ \mathrm{cm}^{2}$ de solo, respectivamente, logo após à distância de $225 \mathrm{~cm}$ esse valor se eleva chegando a aproximadamente $5 \times 10^{-2} \mathrm{~cm}^{2}$ de raiz $/ \mathrm{cm}^{2}$ de solo. Esse acréscimo deve-se provavelmente ao fato de ser este local onde se faz uso da prática de adubação ao qual propiciou um desenvolvimento acentuado de raízes em relação as distância de 200 e $250 \mathrm{~cm}$.

A presença em maior quantidade tanto do comprimento $\left(\mathrm{cm}\right.$ de raiz $/ \mathrm{cm}^{2}$ de solo) quanto densidade de raiz $\left(\mathrm{cm}^{2}\right.$ de raiz $/ \mathrm{cm}^{2}$ de solo) na camada de $0-25 \mathrm{~cm}$ pode ser explicada, devido a esta camada apresentar uma maior densidade aparente (Tabela 1) o que favorece a uma maior capacidade de retenção de umidade, fato também constatado por Avilán (1974).

Nas Figuras 14 e 15 estão representadas as isolinhas de comprimento e densidade de raiz, respectivamente. Observa-se que ambas possuem um comportamento semelhante, diminuindo a concentração a medida que distancia do tronco e com a profundidade (formato cônico). 


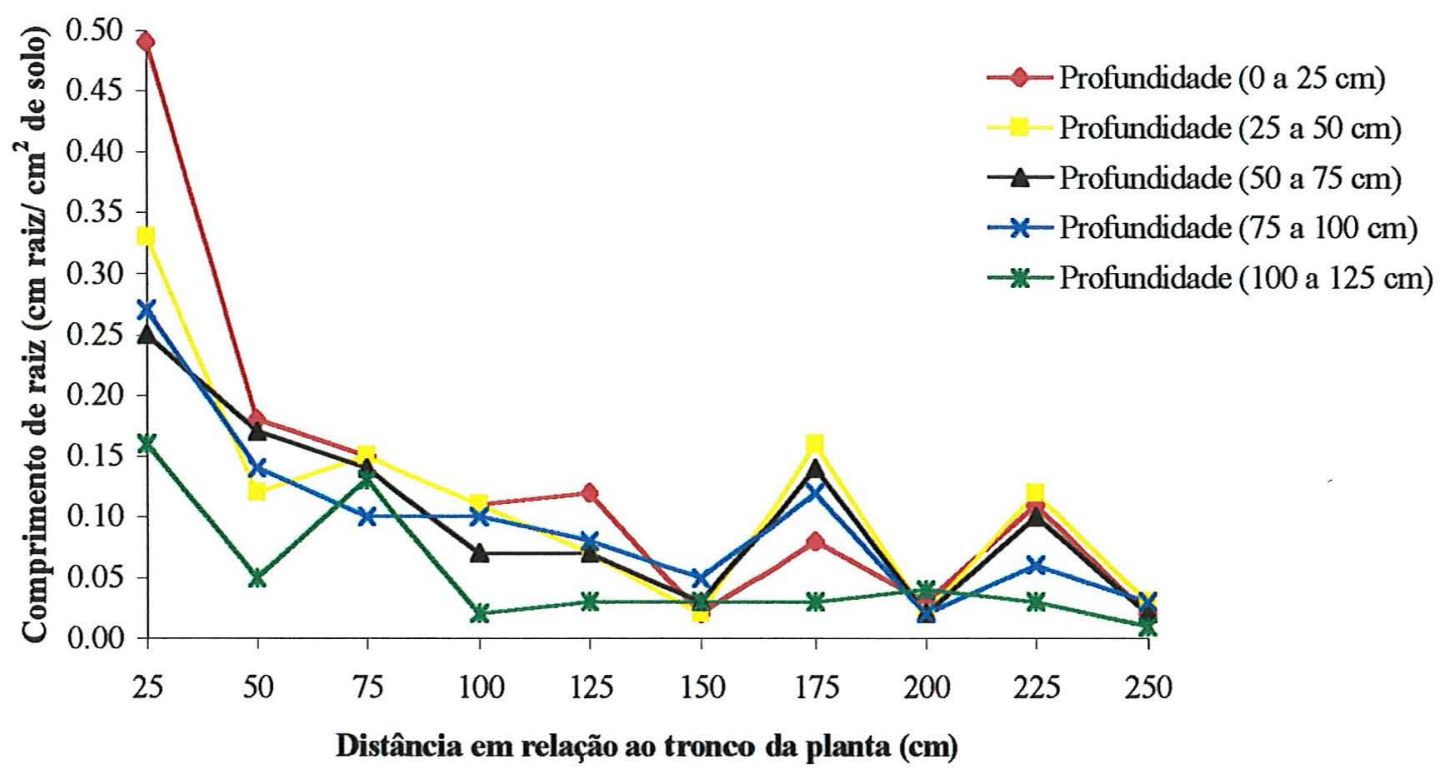

(a)

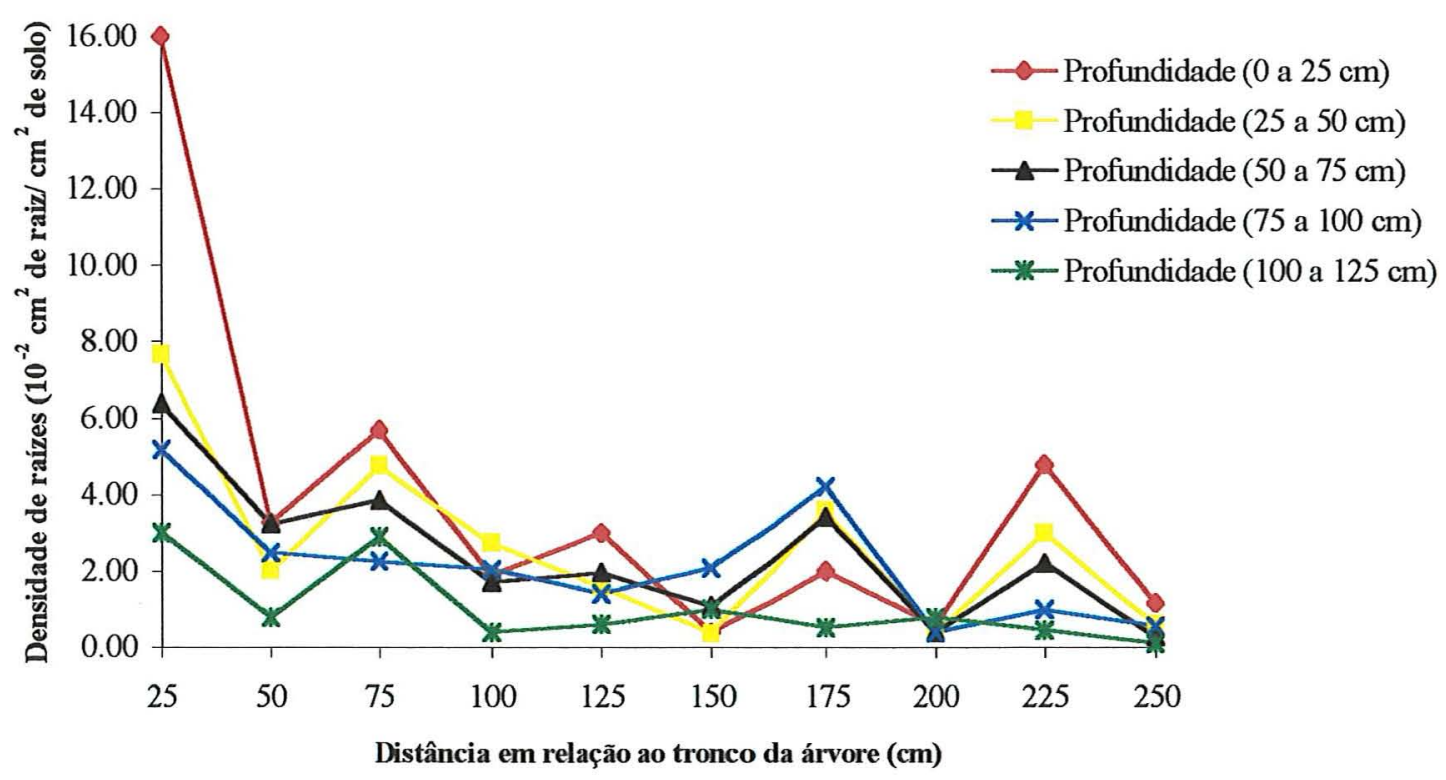

(b)

Figura 12 - (a) Distribuição do comprimento de raiz em função da distância em relação ao tronco da planta, (b) Distribuição da densidade de raiz em função da distância em relação ao tronco da planta. 


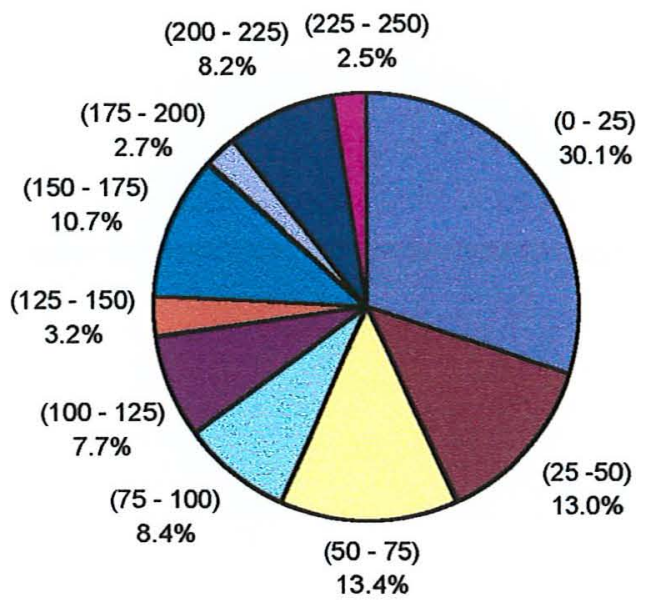

(a)

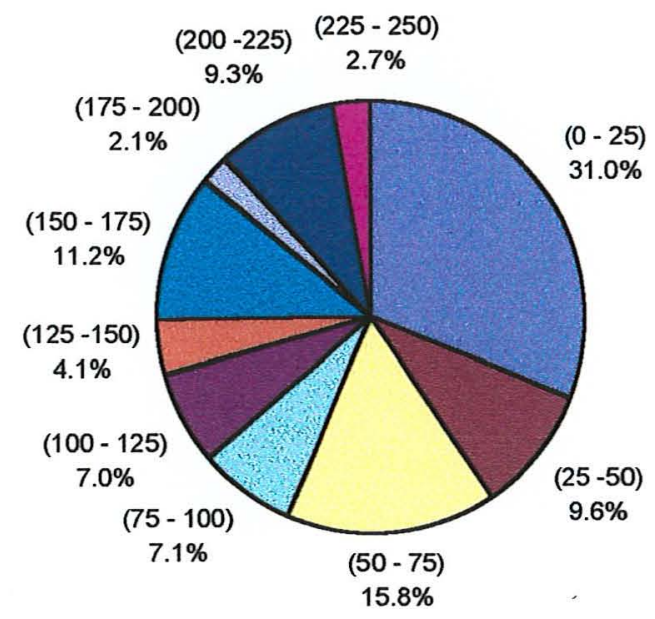

(c)

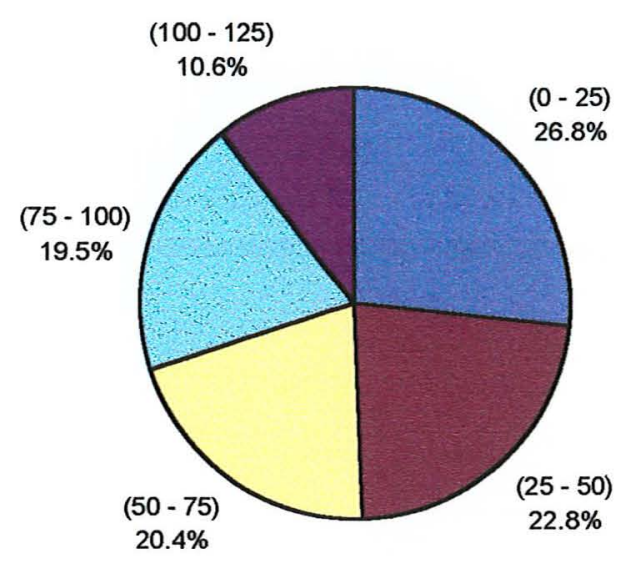

(b)

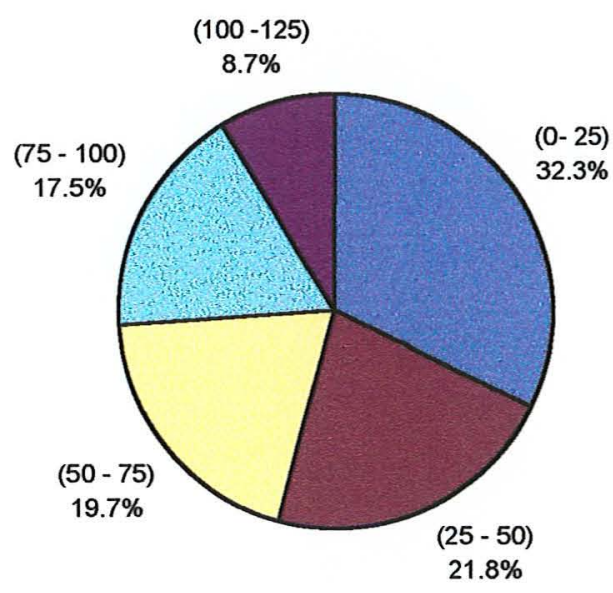

(d)

Figura 13 - (a) Distribuição do comprimento de raiz ( $\mathrm{cm}$ de raiz/ $\mathrm{cm}^{2}$ de solo) em função da distância em cm do tronco da planta, (b) Distribuição do comprimento de raiz em função da profundidade, (c) Distribuição da densidade de raiz $\left(\mathrm{cm}^{2}\right.$ de raiz/ $\mathrm{cm}^{2}$ de solo) em função da distância do tronco da planta, (d) Distribuição da densidade de raiz em função da profundidade . 

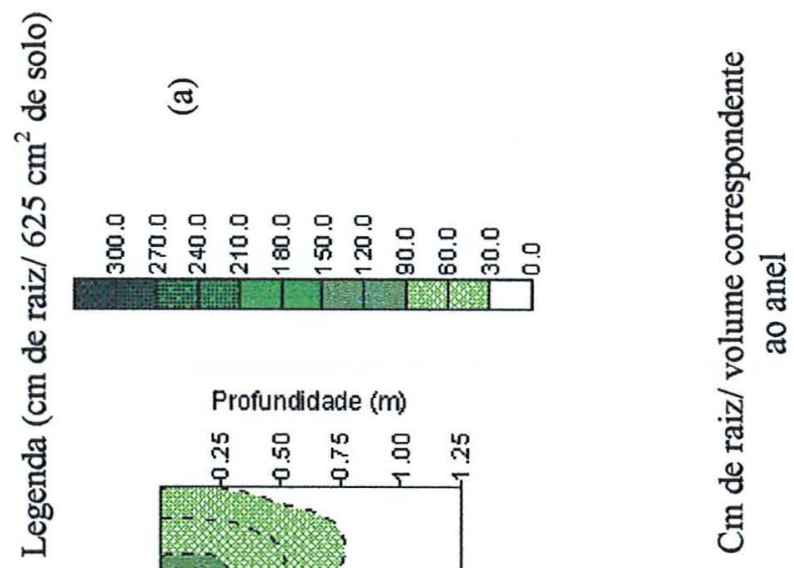

อิ

8

ह్

Profundidade ( $m$ )
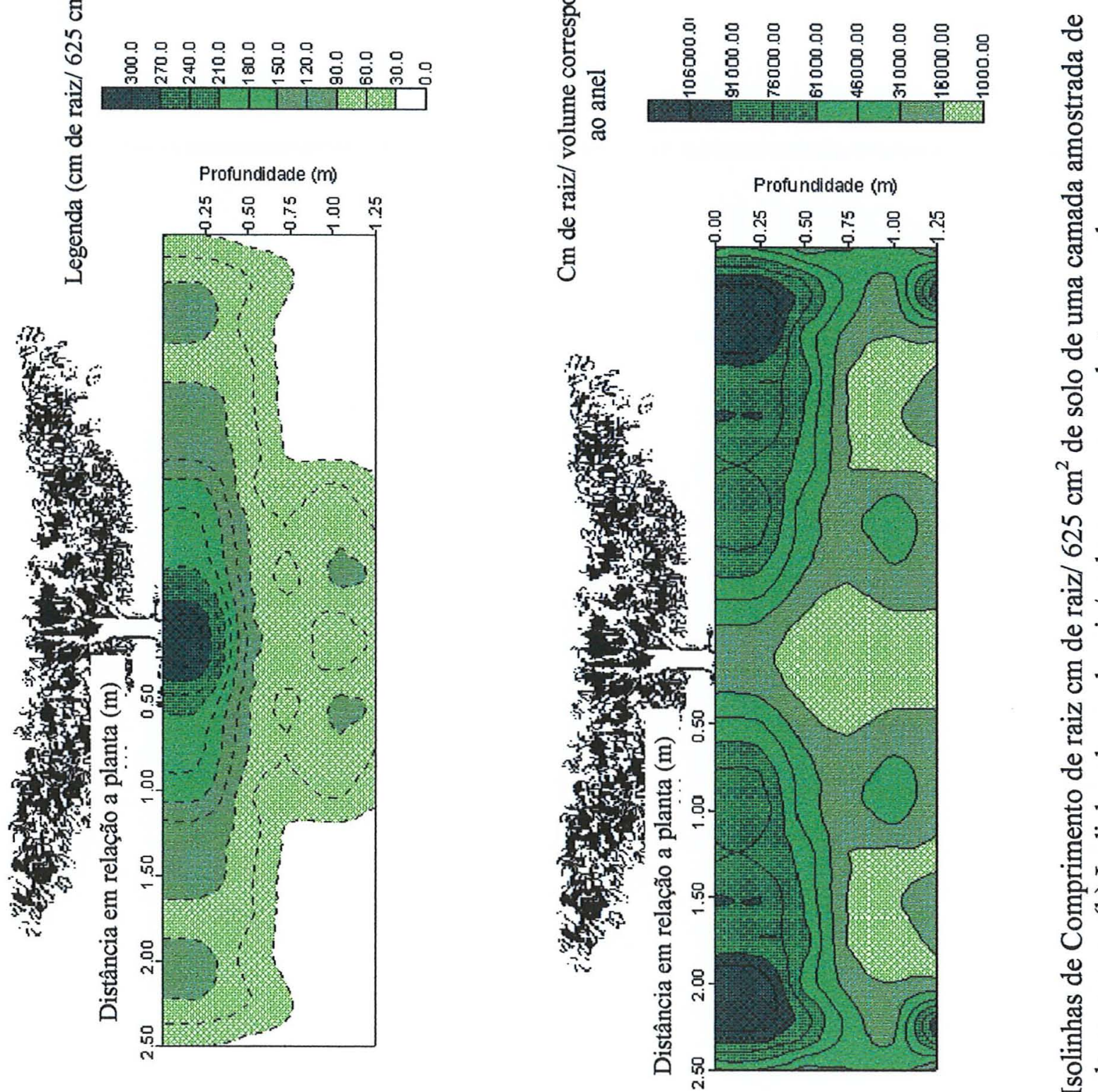

ఫ్త్

范

్ㅗㅇ

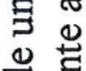

웡

응 뭉

ठㅇ

콩 ठ

됴

궁

전

ชั 존

통 임

그 동

号

임

을

ํㅗㄹ

ํํㅇ

욤

4

壱

응 임

(ึ) 붕

宁

똘 


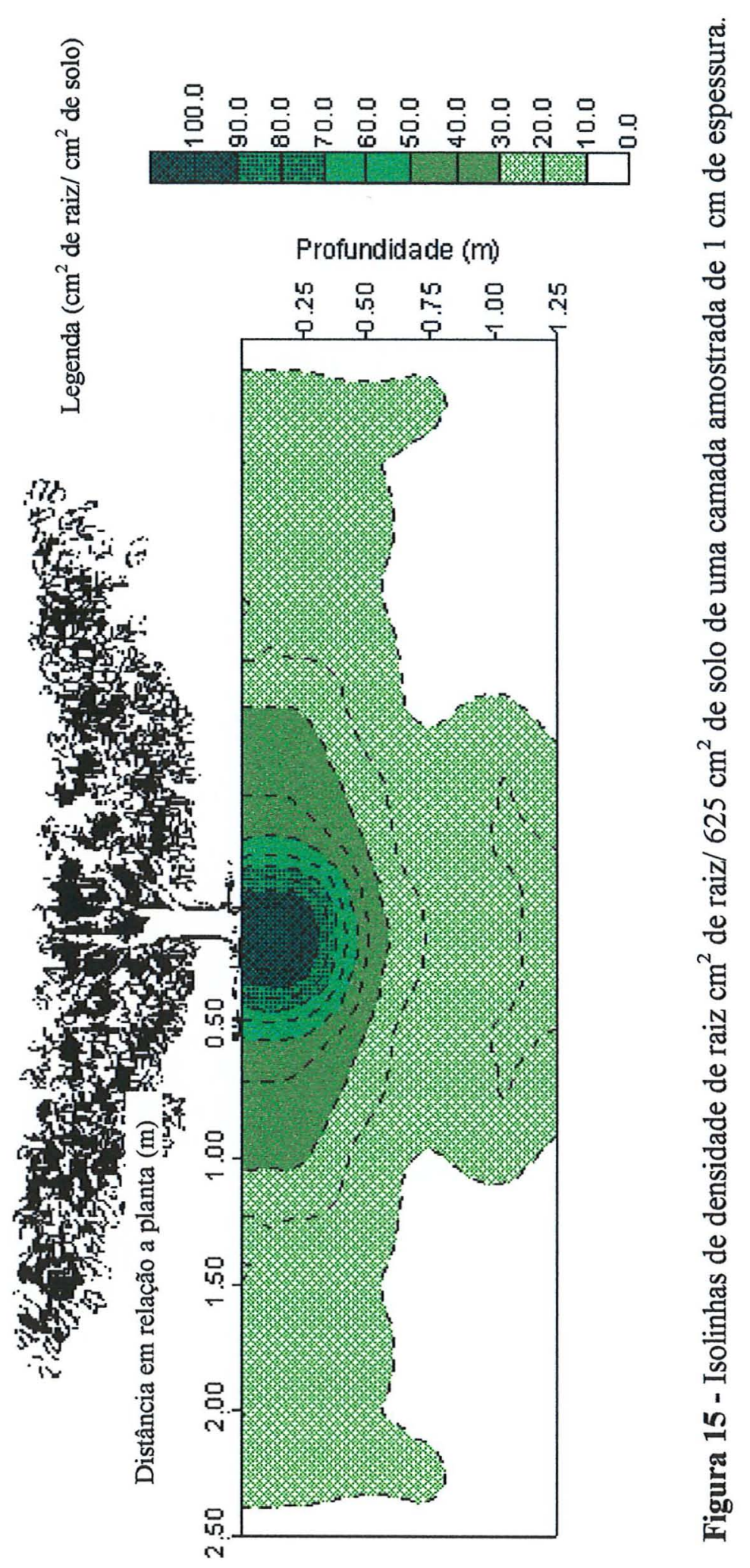




\subsection{Estimativa da atividade radicular.}

Verifica-se por meio da Tabela 7, que existe variação quando a absorção por parte da planta nas diferentes profundidades e nas diversas distâncias em relação ao tronco da planta no entanto, a pequena variação ocorrida a partir de $0,80 \mathrm{~m}$ de profundidade pode ter ocorrido devido ao fato da lâmina de água aplicada não ter atingido a estas profundidade e também, devido ao solo apresentar características argilosa, conforme Tabela 1, o que proporciona uma menor disponibilidade de água para a planta quando em altas tensões. Segundo Kotur et al. (1997) esta variação esta associada ao teor de água no solo.

A evapotranspiração nos primeiros $0,10 \mathrm{~m}$ de profundidade foi superior a demais camadas, isto ocorreu devido a esta apresentar-se expostas ao intempéries do meio ou seja maior incidência de radiação solar e expostas ao vento o que proporciona uma maior evaporação, sendo necessário quando da aplicação desta metodologia a utilização de uma cobertura total do local onde se estar analisando.

De posse dessa tabela, adotou-se as profundidades de 0,$20 ; 0,40 ; 0,60$; 0,80 e $1,00 \mathrm{~m}$ para todas as distâncias em relação ao tronco da planta, para estimar a atividade radicular ou consumo da solução do solo por parte da planta. Estas profundidades foram selecionadas haja vista que $89,4 \%$ e $91,3 \%$ do comprimento e densidade de raiz, respectivamente, estão a 1,00 m.

Do consumo total da solução do solo por parte da planta cerca de $75,58 \%$ restringi-se até a distância de $1,50 \mathrm{~m}$ a profundidade de $0,80 \mathrm{~m}$ (Figura 16). Substancial proporção encontra-se na camada de $0-0,20 \mathrm{~m}(48,36 \%)$, para as profundidades de 0,40 ; 0,60 e $0,80 \mathrm{~m}$ tem-se $20 \%, 9,6 \%$ e $13 \%$, respectivamente. 


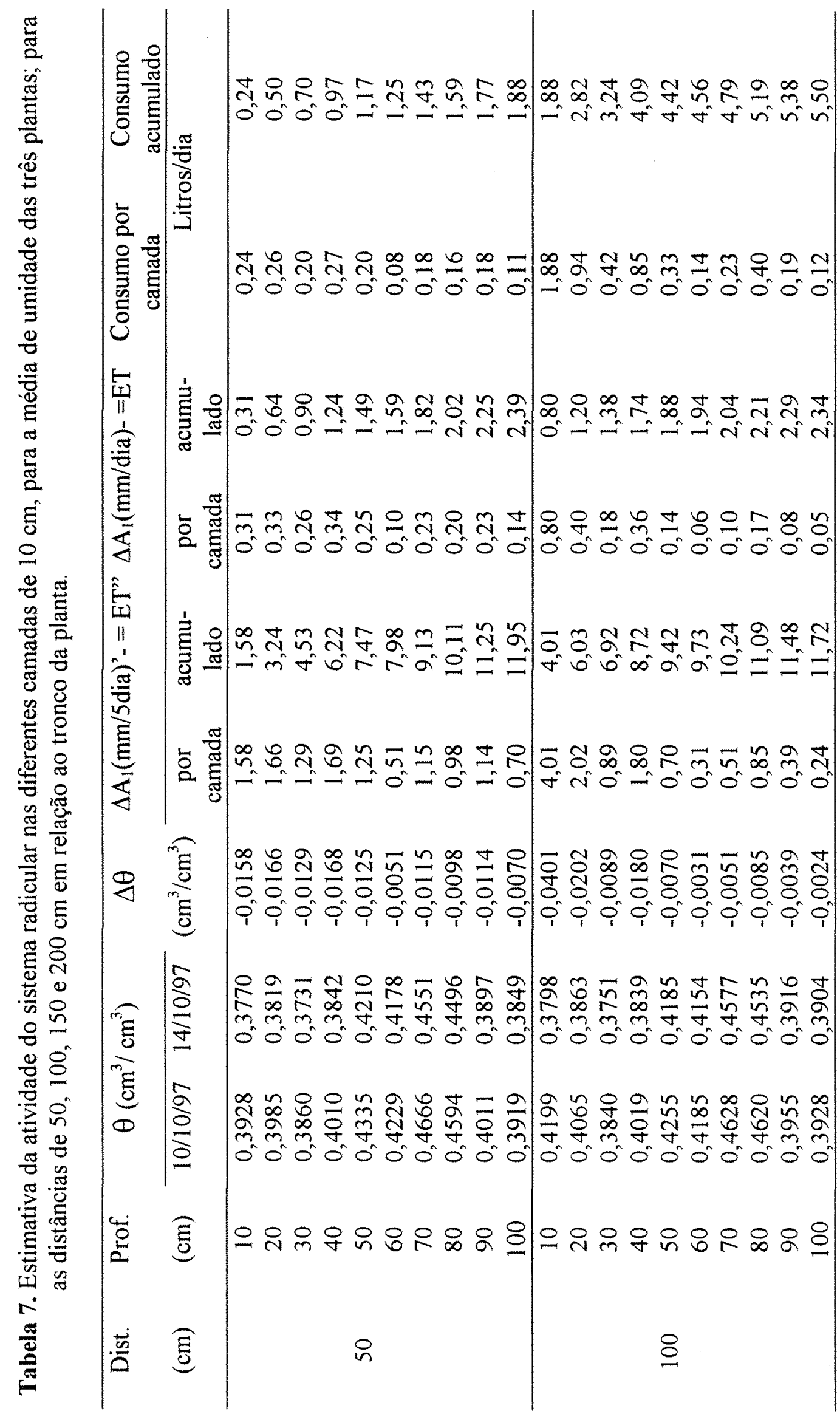




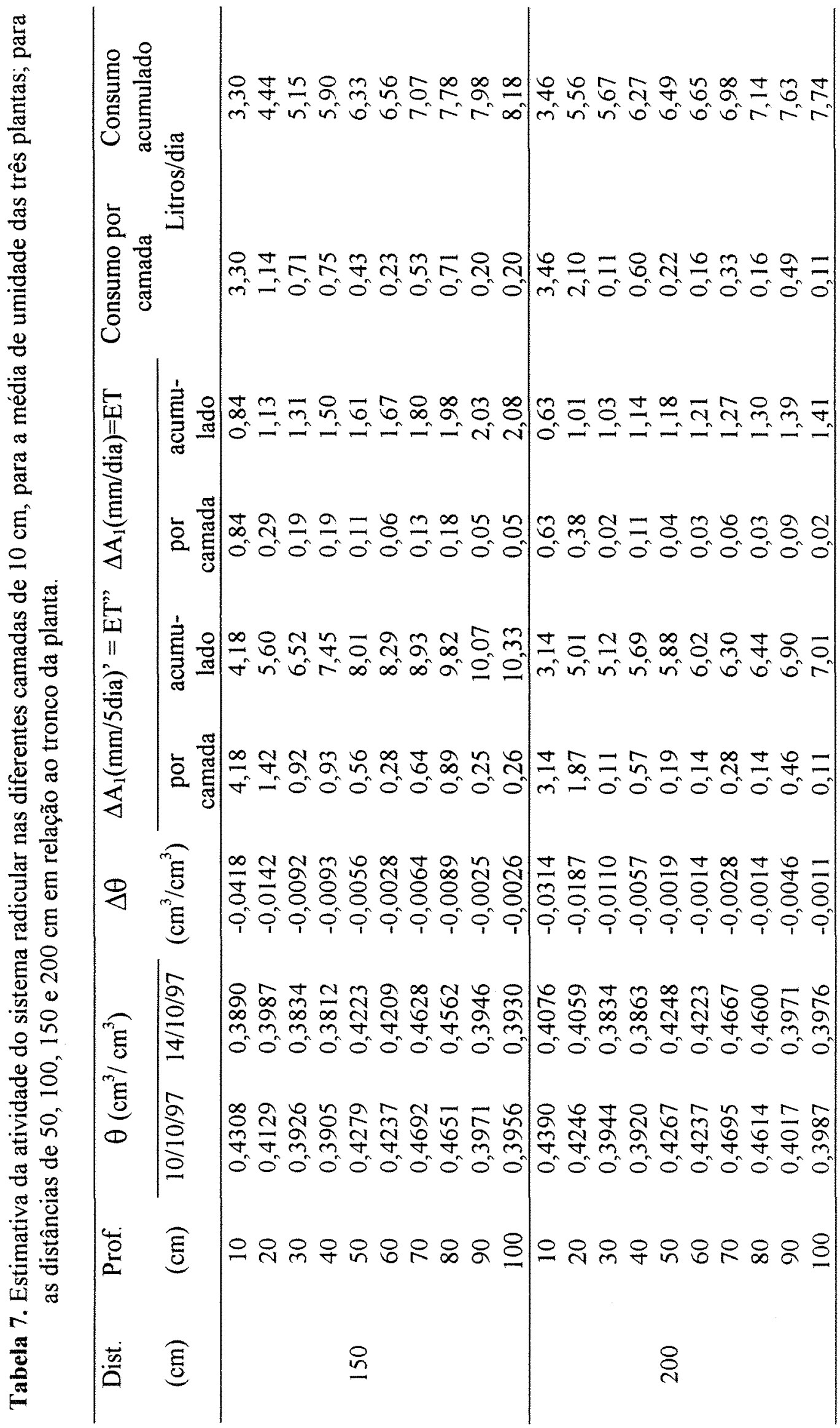




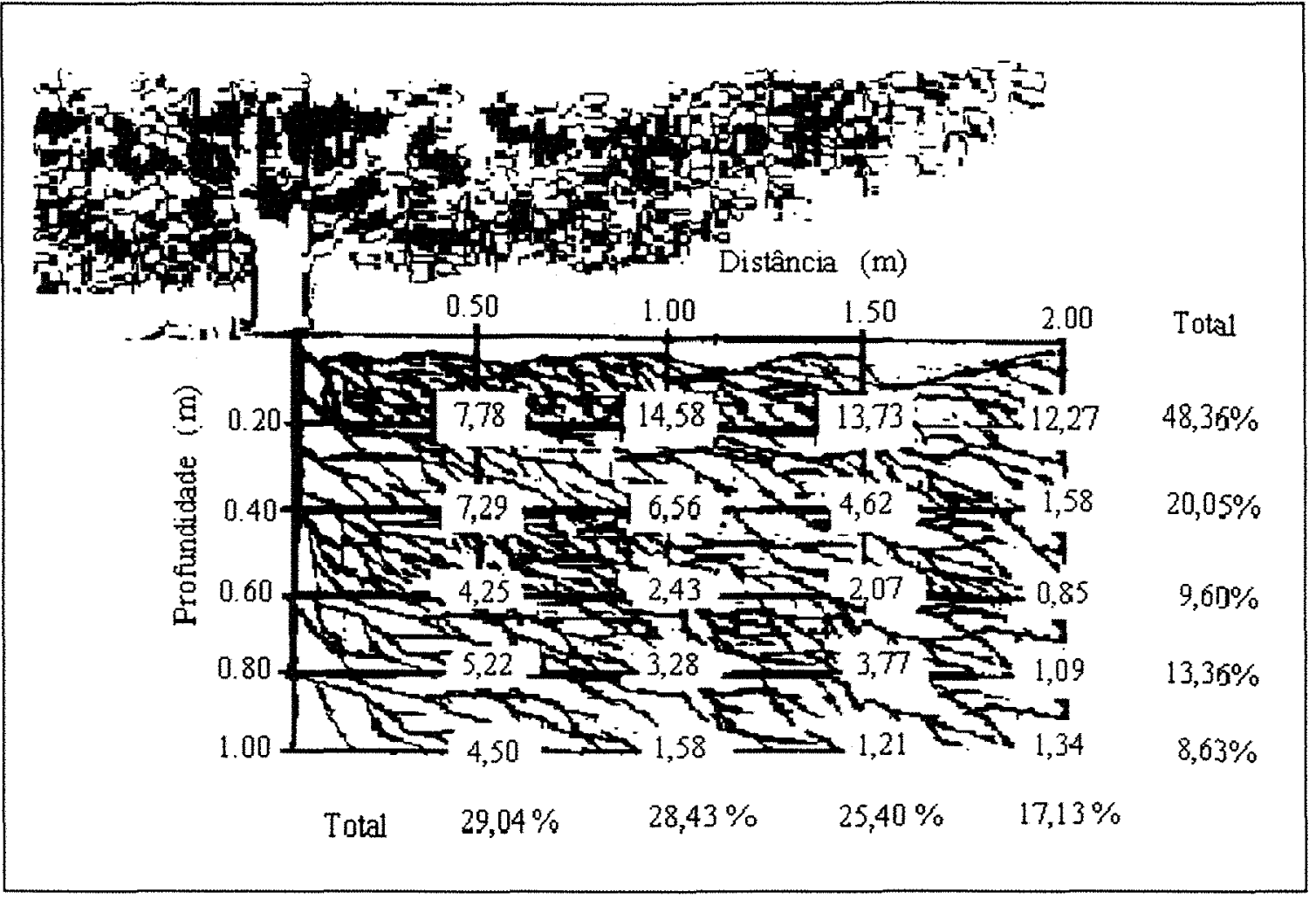

Figura 16 - Estimativa do consumo da solução do solo em função da lâmina (mm).

Ao analisarmos conjuntamente as Figuras $16,12 \mathrm{a}$ e $12 \mathrm{~b}$, observa-se que para as profundidades de 60 e $80 \mathrm{~cm}$ temos como média de todo perfil aproximadamente $0,25 \mathrm{~cm}$ de raiz/ $\mathrm{cm}^{2}$ de solo (Figura 12a) e $2,4 \times 10^{-2} \mathrm{~cm}^{2}$ de raiz/ $\mathrm{cm}^{2}$ de solo (Figura 12b), logo neste ponto temos também baixa atividade radicular como mostra a Figura 16.

Resultados similares foram constatados por Kotur et al. (1997), que trabalhando com técnica radioativa durante período chuvoso (setembro - novembro, final das chuvas de verão) inverno (dezembro - fevereiro) e verão (março - maio), constatou que $80 \%, 80 \%$ e $53 \%$, respectivamente, da atividade radicular estava a distância de 100 $\mathrm{cm}$ em relação tronco da planta e que $46 \%, 30 \%$ e $43 \%$ da atividade restringia-se a camada de 0-20, respectivamente; e por Bojappa \& Singh (1974), que trabalhando também com técnicas radioativas, verificaram que a maior atividade radicular da mangueira situa-se a $120 \mathrm{~cm}$ de distância do caule e a $15 \mathrm{~cm}$ profundidade do solo. 


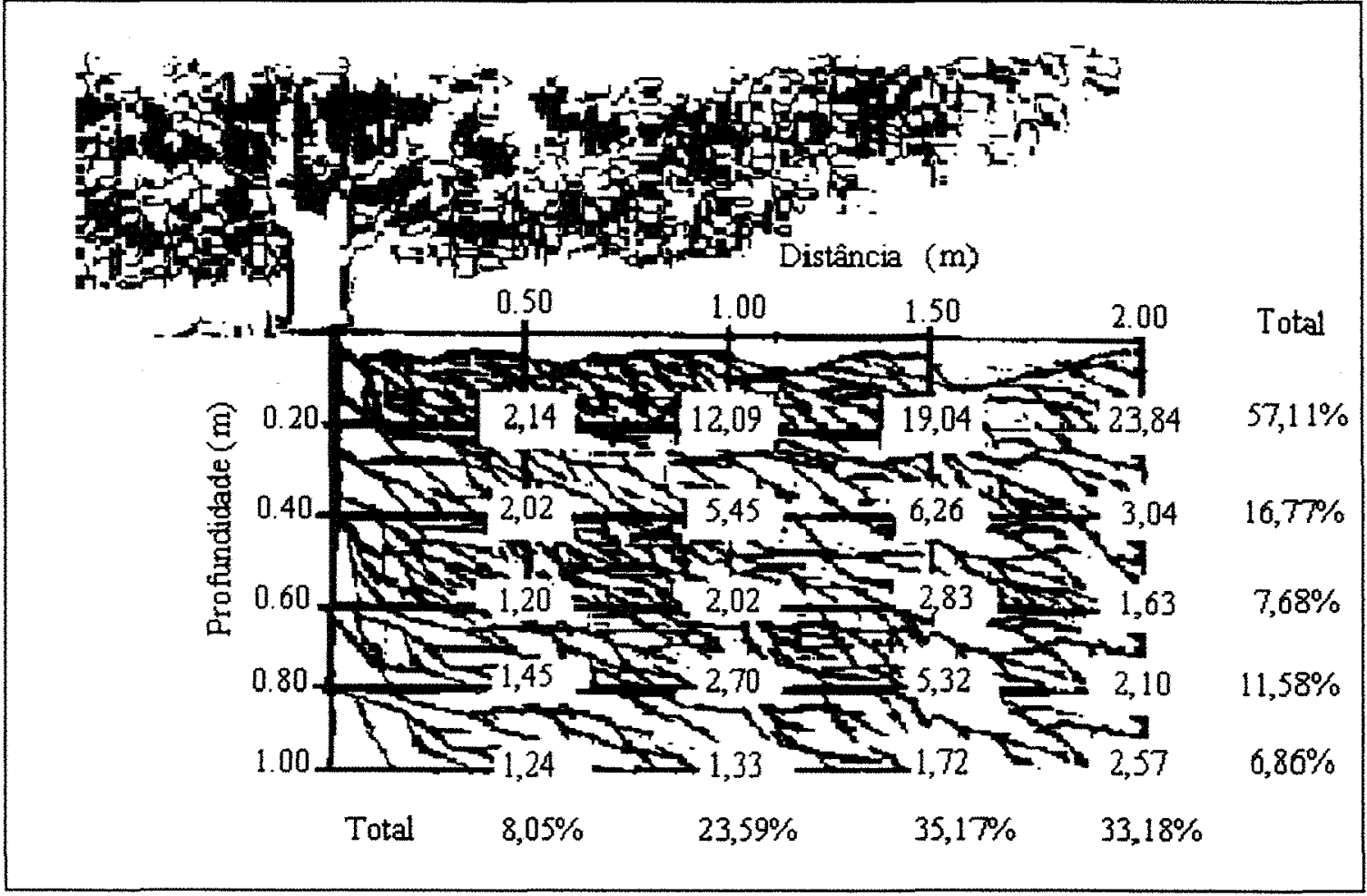

Figura 17 - Estimativa da atividade radicular em função do consumo da solução do solo (litros)

Observa-se por meio da Figura 17, que a maior contribuição em litros de solução do solo para a planta está na faixa de 1,5 e $2,0 \mathrm{~m}$ do tronco da planta na profundidade de $0-0,20 \mathrm{~m}$, as qual foram de 4,44 e 5,56 litros conforme Tabela 7, isto porque envolve uma maior área de raiz, e provavelmente a um maior número de pelos absorventes ou raízes jovens, as quais segundo Kramer (1989), apresentam maior condutividade hidráulica ou permeabilidade, resultando assim em maior capacidade de absorção. No entanto, para as profundidades de $0,20,0,40,0,60$ e $0,80 \mathrm{~m}$ a maior contribuição esta na faixa de 1,00 e 1,50 m do tronco.

$\mathrm{Na}$ Figura 18a, estão apresentadas as isolinhas de potencial total para o dia 10/10/97, nota-se que à planta absorvia solução do solo de uma região limitada à uma distância de $1,0 \mathrm{~m}$ em relação ao tronco da planta até a profundidade de $0,30 \mathrm{~m}$, quando passados 5 dias ou seja no dia 14/10/97, esta região conforme Figura $18 b$, foi ampliada para 2,0 de distância em relação ao tronco da planta até a profundidade de $0,50 \mathrm{~m}$, 
mostrando assim que à medida que o solo a potencial total da solução do solo próximo a planta aumenta esta tende a buscar a solução de pontos mais distantes, tais inferências podem ser realizadas, haja vista que o decréscimo do teor de água no solo estava apenas em função da evapotranspiração da cultura. 

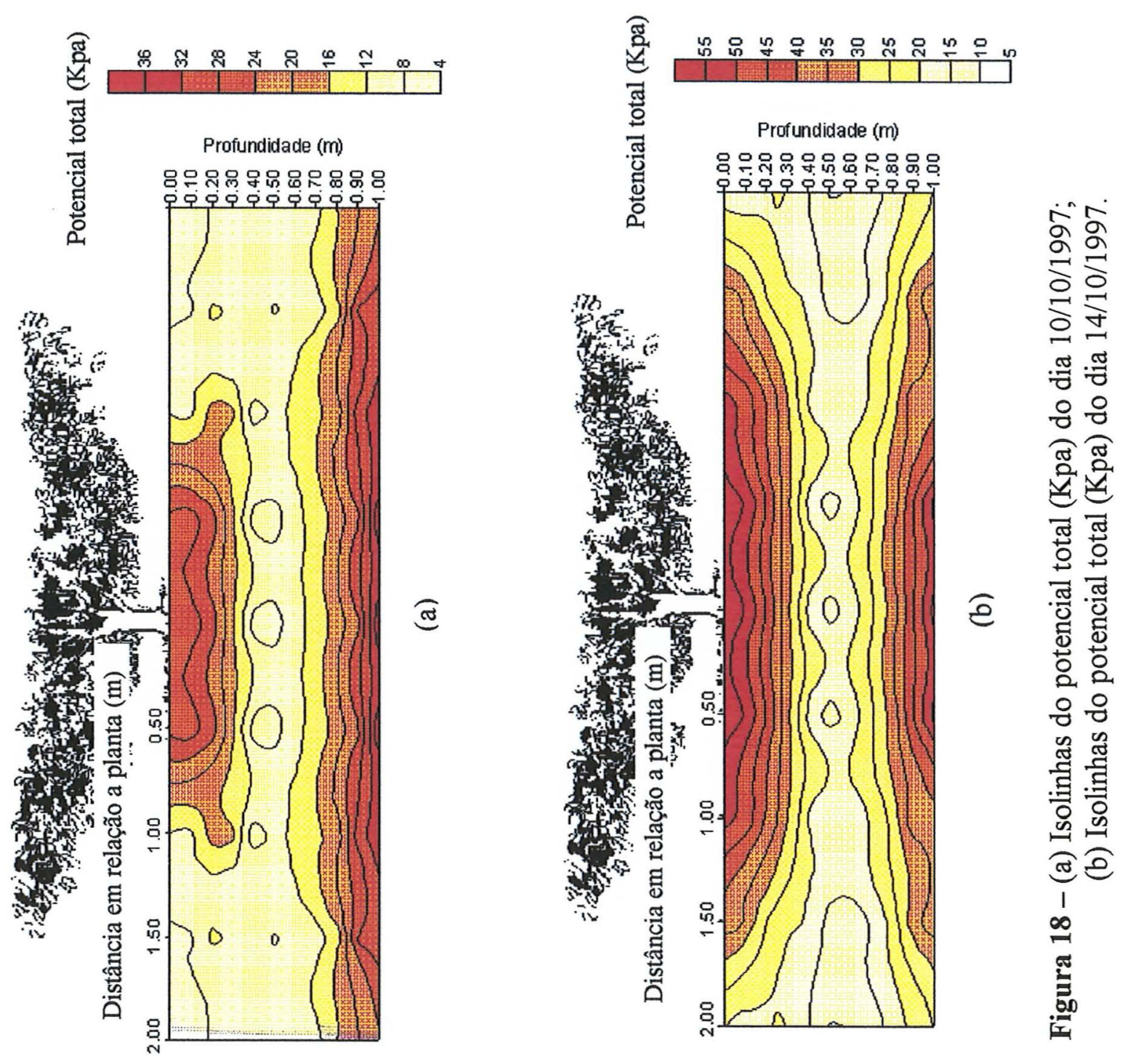


\section{CONCLUSÕES.}

A partir dos resultados obtidos, pode-se concluir que:

- Para fins de monitoramento de irrigação localizada na cultura da manga, o posicionamento ideal dos tensiômetros deverá ser o seguinte: a) distância horizontal em relação ao tronco da planta - 100 a $150 \mathrm{~cm}$; b) distância vertical em relação à superficie do solo: 20,40 e $60 \mathrm{~cm}$.

- A zona radicular que apresenta maior variação de umidade no perfil do solo, localizase próximo ao tronco da planta e coincide com a zona de maior concentração radicular, calculada pela digitalização da imagem do perfil em uma camada amostrada com $1 \mathrm{~cm}$ de espessura.

- A zona radicular responsável pela absorção do maior volume de solução do solo, não coincide com a zona que apresenta a maior variação de umidade no perfil. Esta zona, localiza-se próximo a projeção da copa e coincide com a zona de maior concentração de raízes ponderada pelo volume de solo correspondente ao anel de cada quadrícula do perfil digitalizado.

- Os tensiômetros digital mostrou-se eficiente no cálculo do balanço hídrico na cultura da manga. 


\section{REFERÊNCIAS BIBLIOGRÁFICAS}

FNP. CONSULTORIA \& COMERCIO. AGRIANUAL 98: Anuário estatístico de agricultura brasileira. São Paulo, 1998. p.275-286: Para o deleite dos europeus.

ATKINSON, D. The distribution and effectiveness of root of the crops. Horticultural Reviews, v. 2, p.424-490, 1980.

AVILÁN, R. L. Sistema radicular del mango. (Mangifera indica) en un regosol aluvial. Agronomia Tropical, v.24, n.1, p.3-10, 1974

AVILÁN, R. L.; MENESES, L. Efecto de las propiedades fisicas del suelo sobre la distribuición de las raíces del mango (Mangifera indica L.). Turrialba, v.29, n.2, p.117-121, 1979 .

AVILÁN, R. L.; MENESES, L; GUADARRAMA, A. Estudio de los sistemas radiculares del mango (Mangifera indica L.) y del grapefruit (Citrus paradisi MacFadyen) cultivados en suelos de los llanos centrales de Venezuela. Agronomia Tropical, v.29, n.2, p.173-183, 1979.

BÖHM, W. Methods of studying root systems. Berlin: Springer-Verlag, 1979. 527p. 
BOJAPPA, K. M.; SINGH, R. N. The feeder root distribution patern of young and old mango (Mangifera indica L.): tree. Indian Journal of Horticultural, v.32, p.123 $127,1973$.

BOJAPPA, K. M.; SINGH, R. N. Root activity of mango radiotracer tecnique using ${ }^{32} \mathrm{P}$. Indian Journal of Agricultural Sciences, v.44, n.4, p. 175-180, 1974.

CASTLE, W. S. Fibrous root distribution of "Pineapple"orange tree on rough lemon rootstock at three spacings. Journal of the American Society for Horticultural Science, v. 105, n. 3, p. $478-480,1980$.

CHOUDHURY, E. M.; SOARES, J. M. Comportamento do sistema radicular de fruteiras Irrigadas. I. Mangueira em solo arenoso sob irrigação por aspersão sobcopa. Revista Brasileira de Fruticultura, v. 14, n.3, p.169 -176, 1992.

CINTRA, F. L. D.; NEVES, C. S. V. J. Aspectos metodológicos do estudo do sistema radicular de plantas perenes através de imagens. Boletim Informativo da Sociedade Brasileira de Ciência do Solo, v.21, n.3, p.91-94,1996.

CRESSWELL, H. P. Evaluation of the portable pressure transducer techinique for measuring field tensiometers. Australian Journal of Soil Research, v.31, p.397406, 1993.

CRESTANA, S.; GUIMARÃES, M. F.; JORGE, L. A. C.; RALISCH, R.; TOZZI, C. L.;ORRE, A.;.VAZ, C. M. P. Avaliação da distribuição de raízes no solo auxiliada por processamento de imagens digitais. Revista Brasileira de Ciência do Solo, v.18, n.3, p. 365-371, set./dez. 1994. 
CRUCIANI, D.E. Balanço hídrico em solo cultivado com cana de açúcar. Piracicaba: CENA, 1972. 32p.

EMPRESA BRASILEIRA DE PESQUTSA AGROPECUÁRIA. Centro Nacional de Pesquisa e Desenvolvimento de Instrumentação Agropecuária. Recomendações práticas para análise de imagens digitais através do SIARCS. São Carlos, 1996. (No prelo).

EMPRESA BRASILEIRA DE PESQUISA AGROPECUÁRIA. Serviço Nacional de Conservação e levantamento de Solo. Manual de métodos de análise de solo. Rio de Janeiro, 1979. 1v.

FANTE JÚNIORL L. Sistema radicular de aveia forrageira avaliado por diferentes métodos, incluindo processamento de imagens digitais. Piracicaba, 1997. 119p. Tese (Doutorado) - Centro de Energia Nuclear na Agricultura, Universidade de São Paulo.

FAO QUARTERLY BULLETIN OF STATISTICS, v.8, n.3/4, p.32-33, 1995.

FAO QUARTERLY BULLETIN OF STATISTICS, v.9, n.3/4, p.112-113, 1996.

FARRÉ, J. M.; HERMOSO, J. M. Mulching and irrigation effects on growth, cropping and fruit quality of the mango cv. Sensation. Acta Horticulturae, n.341, p.295 - 302, 1993

FICUS, E. L.; MARKHART, A. H. Relationship between root system transport properties and size in Plaseolus. Plant Physiology, v.64, p.770-773, 1979. 
FORD, H. W. Effect of spreading decline disease on the distribuition of feeder roots of orange and grapefruit trees on rough lemon rootstock. Proceedings of the American Society for Horticultural Science, v. 61, p. 68-72, 1953

HILLEL, D. Solo e água: fenômenos e princípios fisicos. Porto Alegre: Universidade Federal do Rio Grande do Sul. 1970. 231 p.

HUCK, M. G.; TAYLOR H. M. The rhizotrons as a tool for root research. Advances in Agronomy, v.35, p. 1-35, 1982.

KRAMER, P. J. Water relations of plants. Orlando: Academic Press Inc., 1983. 489p.

KHAN, M. -UD-D. Systems of mango (Mangifera indica L.). Punjab Fruit Journal, v.23, n.82/83, p.113-116. 1960.

KLAR, A. E. A água no sistema solo planta atmosfera. São Paulo: Nobel, 1984. 408p.

KOPKE, U. Methods for studing root growth. In: RUSSEL, R. S.; IGUE, K.; MEHTA, Y. R. (Ed.) The soil/root systems in relation to brasilian agriculture. Londrina: Fundação Instituto Agronômico do Paraná, 1981. p.303-318.

KOTUR, S. C.; IYENGAR. B. R. V.; SHIVANANDA, T. N. Distribution of root activity in young "Alphonso" mango (Mangifera indica) trees as influenced by season and growth. Indian Journal of Agricultural Sciences, v.67 n.3, p.113-116, Mar. 1997.

LIBARDI, P. L. Dinâmica da água no solo. Piracicaba: ESALQ, Depto. Física e Meteorologia, 1995. 497p. 
MARTHALER, H.P.; VOGELSANGER,W.; RICHARD, F.; WIERENGA, P. J. A pressure transducer for field tensiometers. Soil Science Society of America Journal, v. 47, n. 4, p. $624-627,1983$.

MEDINA-URRUTIA, V. M. Fibrons Root Distribution of mango (Mangifera indica L.) and tamarind (Tamarindus indica L.) tree. Proceedings of the Florida State Horticultural Society, v.97, p.363-366. 1984.

MONTENEGRO, H. W.S. Contribuição ao estudo do sistema radicular das plantas cítricas. Piracicaba, 1960. 143p. Tese (Cátedra). - Escola Superior de Agricultura "Luiz de Queiroz", Universidade de São Paulo.

OMETTO, J. C. Registros e estimativas de parâmetros meteorológicos da região de Piracicaba, SP. Piracicaba, FEALQ, 1991. 76p.

PACE, C. A. M.; ARAÚJO, C. M. Estudo da distribuição do sistema radicular de portaenxertos cítricos em solos podzolizados e sua relação com a formação de copas. In: CONGRESSO BRASILEIRO DE FRUTICULTURA, 8, Brasília 1986. Brasília: SBF, 1986. v.1, p.199-205.

PAES de CAMARGO, A.; GROHMANNF.; PAES de CAMARGO, M,B. Tensiômetro simples de leitura direta. Pesquisa Agropecuária Brasileira, v.17, n.12 p.1763$1772,1982$.

REICHARDT, K. A água no sistemas agrícolas. São Paulo: Manole, 1990. 188p.

REICHARDT, K.; LIBARDI.; P. L.; SAUNDERS, L. C. U.; CADINA; A. Z. Dinâmica da água em solo cultivado com milho. Revista Brasileira de Ciência do Solo, v.3, n. 1, p.1-5, jan/abr. 1979. 
ROJAS, A. J. A. Distribuição do sistema radicular de cultivares de mangueiras (Mangifera indica L.) em latossol. Piracicaba, 1989. 58p. Dissertação (Mestrado) Escola Superior de Agricultura "Luiz de Queiroz", Universidade de São Paulo.

SAAD, A. M. Uso do tensiômetro no controle da irrigação por pivô central Piracicaba, 1991. 141p. Dissertação (Mestrado.) - Escola Superior de Agricultura "Luiz de Queiroz", Universidade de São Paulo.

SAAD, A. M. Déficit de irrigação como estratégia de manejo da água em feijoeiro (Phaseolus vulgaris L.). Piracicaba, 1996. 127p. Tese (Doutorado) - Escola Superior de Agricultura "Luiz de Queiroz", Universidade de São Paulo.

SCALOPPI, E. J. Critérios básicos para seleção de sistemas de irrigação. Informe Agropecuário, v. 12, n.139, p.54 - 62, 1986.

SHUURRMAN, J. J.; GOEDEWAAGEN, M. A. J. Methods of the examination of root systems and roots. 2.ed. Wageningen: Pudoc, 1971. 86p.

SIMÃO, S. Manual de fruticultura. São Paulo: Ceres, 1971. 530p

STHEPHENES, S. E. The mango in Queensland. Queensland Agricultural Journal v. 7, n. 68, p. $146-208,1949$.

TAYLOR, H. M; UPCHURCH, D. R.; BROWN, J. M; ROGERS, H. H. Some methods of root investigations. In: McMICHAEL, B. L.; PERSSON, H. (Ed.) Plant roots and their envionment. Amsterdan: Elsevier Science, 1988 p. 515-525. 
THAKUR, R. S.; RAJPUT, M. S.; SRIVASTAVA, K. C. Root distribuition studies in some fruit croops with special reference to tracer technique: a review. Haryana. Journal of Horticultural Science, v. 10, n. 1/2, p. 45-53, 1981.

THIEL, T. J.; FOUSS, J. L.; LEECH, A. P. Electrical water pressure transducers for field and laboratory use. Soil Science Society of America Proceedings, v.27, n.5, p. 601-602, 1963.

VAN GENÜCHTEN, M. Th. A closed - form equation for predicting the hydraulic conductivity of unsaturated soils. Soil Science Society of America Journal, v.44, p.892-898, 1980.

ZANETTE, F; COMEM, J. J. Estudo do sistema radicular das plantas. In: REUNIÃO BRASILEIRA DE FERTILIDADE DO SOLO E NUTRIÇÃO DE PLANTAS, Piracicaba, 1992. Anais. Piracicaba: Fundação Cargill, 1992. p. 395 - 403. 